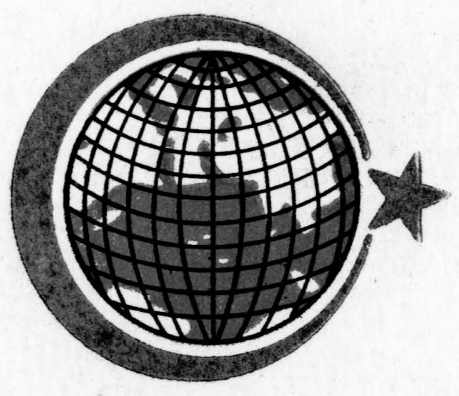

\title{
AFGHANISTAN REPORT
}

NO. 38

MAY 1987

CRISIS \& CONFLICT ANALYSIS TEAM

THE INSTITUTE OF STRATEGIC STUDIES

SECTOR F-5/2, P. O. BOX 1173,

ISLAMABAD-PAKISTAN 


\section{CRISIS AND CONFLICT ANALYSIS TEAM (CCAT) AFGHANISTAN}

\section{Chairman}

Project Coordinators

Associates

\section{. Kamal Matinuddin,}

. Ijaz S. Gilani Naseem Rizvi

. Najam Abbas Fazal-ur-Rahman

1. The Crisis and Conflict Analy sis Team comprises of leading academicians, strategists, researchers and policy analysts interested in the study of international relations. The members of this team meet periodically in groups; one team is devoted to the study of the Afghan crisis and conflict. In the light of carefully monitored information each group reviews current developments in its respective conflict area, and offers various policy options for consideration. While the Institute of Strategic Studies provides the forum, coordinates research and publishes the findings of the Crisis and Conflict Analysis Team, it does not necessarily share the views expressed by the team members whose participation in this group is in their individual capacity.

2. The information and overt intelligence incorporated in this report after collection, collation, and evaluation is based on primary and secondary sources of all the parties in the conflict. The primary sources availed are the monitoring reports of Pakistan Broadcasting Corporation covering Moscow, Tashkent, Dushambe and Kabul broadcasts, Afghan, Soviet, and other Embassy handouts, and information received from the Afghan Documentation Centre, Afghan Information Centre, the Afghan Islamic Press, and the Agency Afghan Press files. Secondary sources are the international media, and research papers and writings of the academicians. We are aware of the paucity of correct, complete and timely information from closed societies, as also the lack of formal and trained command, control, communication and intelligence set-up in the Mujahideen, as present in regular armies.

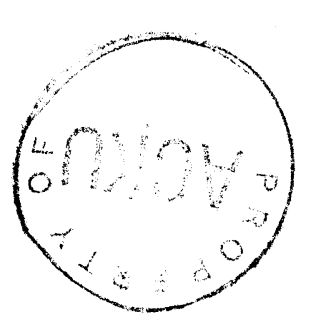




\section{AFGHANISTAN REPORT MAY 1987}

IJ AZ S. GILANI

NASEEM RIZVI

Edited and Published by Kamal Matinuddin on behalf of the Institute of Strategic Studies vide DM. Islamabad Memo No. 2617/C of 14-7-1985 and despatched under GPO's Registered No. N-1 072, Telephones: 824628, 821340, 824658.

Subscription Rates: Annual Rs. 120.00 Single copy Rs. 10; Overseas Annual US \$ 60.00 ; Single US $\$ 5.00$ including air mail. Address: The Institute of Strategic Studies, Sector F-5/2, Islamabad.

Printed by Abdal Ghani Barq at Ferozsons Rawalpindi Ltd., 32 Saddar Road Rawalpindi, Telephones: $62302-62366-67901$ Telex: 54055 BARQ Pk. 


\section{ACRONYMS}

$\begin{array}{ll}\text { AAP } & =\text { Agency Afghan Press (Mujahideen). } \\ \text { AAPSO } & =\text { Afro-Asian People's Solidarity Organization. } \\ \text { AAWC } & =\text { All Afghanistan's Women Council. } \\ \text { ADBA } & =\text { Agricultural Development Bank of Afghanistan. } \\ \text { ALA } & =\text { Association of Lawyers of Afghanistan. } \\ \text { APC } & =\text { Armoured Personnel Carrier. } \\ \text { CC } & =\text { Central Committee. } \\ \text { CP } & =\text { Communist Party. } \\ \text { DRA } & =\text { Democratic Republic of Afghanistan. } \\ \text { DYOA } & =\text { Democratic Youth Organization of Afghanistan. } \\ \text { HIS } & =\text { Haqiqat-e-Inqilab-e-Saur ('The Truth of the Saur Revolu- } \\ & \text { tion'), daily newspaper. } \\ \text { HMV } & \text { Heavy Military Vehicles. } \\ \text { IHT } & =\text { International Herald Tribune. } \\ \text { IRC } & =\text { International Red Cross. } \\ \text { KHAD } & \text { State Secret Service. } \\ \text { KNT } & =\text { Kabul New Times. } \\ \text { LOSPA } & \text { Local Organs of State Power and Administration. } \\ \text { NFF } & =\text { National Fatherland Front. } \\ \text { NVDP } & =\text { Ningarhar Valley Development Project. } \\ \text { PDPA } & =\text { Peoples Democratic Party of Afghanistan. } \\ \text { POA } & =\text { Pioneers Organization of Afghanistan. } \\ \text { PSFO } & =\text { Peace, Solidarity and Friendship Organization. } \\ \text { RC } & =\text { Revolutionary Council. } \\ \text { SAFS } & =\text { Soviet Afghan Friendship Society. } \\ \text { TUA } & =\text { Trade Unions of Afghanistan. } \\ \text { UJA } & =\text { Union of Journalists of Afghanistan. } \\ \text { UNESCO } & =\text { United Nations Educational Scientific and Cultural Organiza- } \\ & \text { tion. } \\ \text { UNGA } & =\text { United Nations General Assembly. } \\ \text { VFA } & =\text { Voice of Free Afghanistan. } \\ \text { VOA } & =\text { Voice of America. } \\ \text { VOG } & =\text { Voice of Germany. } \\ \text { VOIR } & =\text { Voice of Islamic Revolutionary Afghanistan (reportedly } \\ & \text { based in Iran). } \\ \text { WDS } & =\text { Western Diplomatic Sources. } \\ \text { WHO } & =\text { World Health Organization. } \\ \text { YPO } & =\text { Young Pioneer's Organization. } \\ \text { 'Jehad' } & =\text { To strive, struggle, resist, fight against, as an article of Faith. } \\ \text { 'Mujahideen' } & \text { The of the main tenets of Islam. } \\ \text { 'Jirga' } & =\text { Assembly of Tribal Elders. } \\ \text { 'Loi Jirga' } & \text { National Assembly of Tribal Elders. } \\ \text { 'Afghanis' } & \text { Afghan Currency. } \\ & \end{array}$




\section{TABLE OF CONTENTS}

The Historical Perspective

I. The Fourth Afghan War
. . ISSI Map

. . Hasan Akhter Gardezi

. Najam Abbas

1. Summary Perspective

2. Major Military Engagements _. $\quad \ldots \quad$. . 4

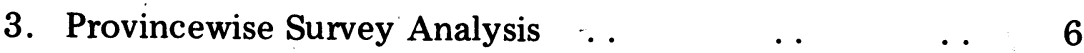

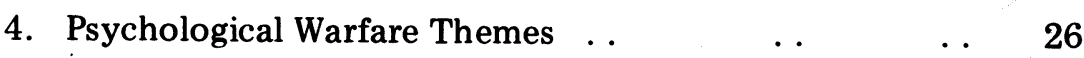

\section{APPENDICES}

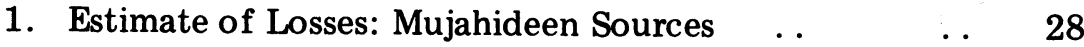

2. Estimate of Losses: Kabul-Moscow Sources. . $\quad \ldots \quad 29$

3. Provincewise Distribution of Engagements: $\begin{array}{lllll}\text { Mujahideen Sources } & \ldots & \ldots & \ldots & 30\end{array}$

4. Mujahideen Mobile and Immobile Targets and Soviet-Kabul Operations: Mujahideen Sources $\quad \ldots \quad 31$

5. Provincewise Security Operations and Returnees Soviet-Kabul Sources

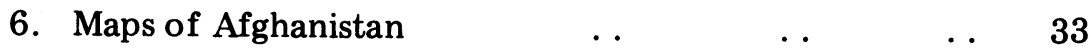

7. May War Reports Comparison with Previous Months .. 35

8. Notes $\quad \ldots \quad 36$

II. The Politico-Economic and Cultural Development in Afghanistan . Naseem Rizvi

1. Foreign Visits and Agreements .. $\quad \ldots \quad \ldots, \quad \ldots \quad 37$

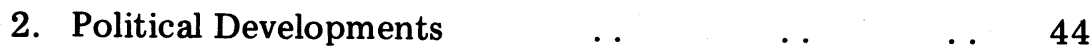

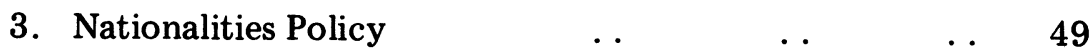

4. Economy _. Fazal-ur-Rahman .. 51

5. Education, Youth and Health .. $\quad \ldots . \quad \ldots \quad 57$

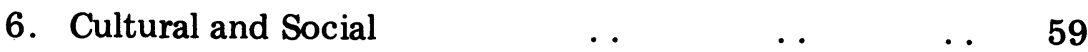




\section{THE HISTORICAL PERSPECTIVE}

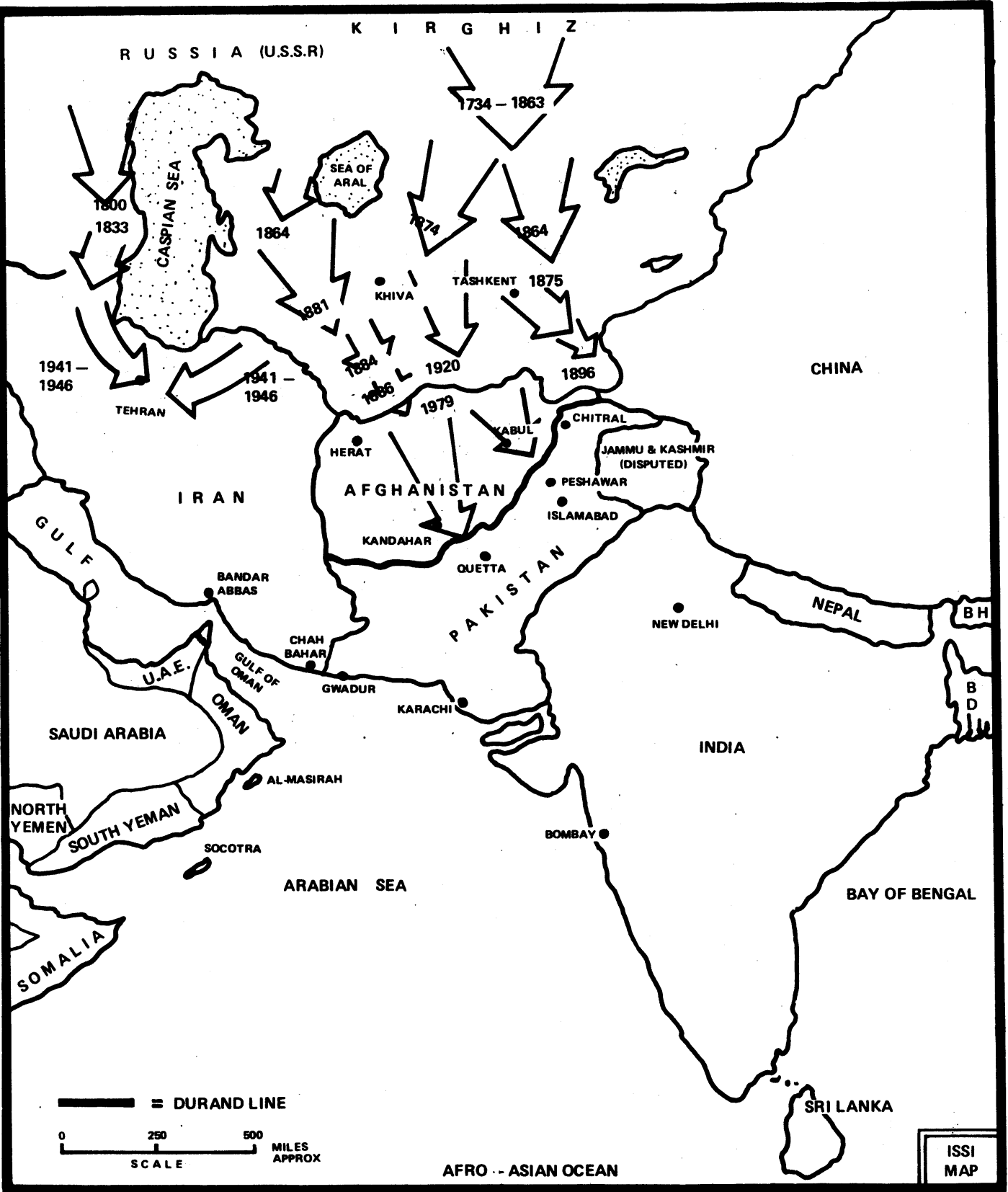




\section{I. - THE FOURTH AFGHAN WAR}

\section{1 - SUMMARY PERSPECTIVE (see map Appendix 6)}

Mujahideen sources reported 431 incidents in 28 provinces and Radio Kabul reported 20 security operations in 8 out of 29 provinces of Afghanistan in May 1987.

The highiest number of engagements was reported from Qandahar, Kabul, Parwan (in that order) followed by Balkh, Kunar and Paktiya.

Conflict was witnessed in 16 provincial capitals, including the country's 4 major cities Kabul, Qandahar, Herat and Mazar. Bomb blasts continued in the capital Kabul in May 1987.

The intensification of war, it would seem, reflects a desire on the part of the combatants-particularly the Soviets and Soviet-sponsored Kabul regime-to have what might be called a favourable position of strength before political negotiations resume at Geneva.

Comparative figures for the number of engagements since the beginning of year are given below in descending order:

\begin{tabular}{lcccc}
\hline Month & $\begin{array}{c}\text { Mujahideen } \\
\text { Operations }\end{array}$ & $\begin{array}{c}\text { Soviet-Kabul } \\
\text { Operations }\end{array}$ & $\begin{array}{c}\text { Total } \\
\text { Engagements }\end{array}$ \\
\hline May & 87 & 335 & 96 & 431 \\
April & 87 & 300 & 198 & 498 \\
March & 87 & 339 & 149 & 488 \\
Feb. 87 & 177 & 35 & 212 \\
Jan. 87 & 309 & 133 & 422 \\
\hline
\end{tabular}

There is evidently a shift in favour of immobile targets. Possibly the Soviet-Kabul, as well as, the Mujahideen are slowly but perceptibly changing tactics to suit the needs of terrain, the level of morale and weapons available to themselves and their adversaries. (See Appendix 7 for yearwise comparison).

i. The Mujahideen are participating with greater frequency and intensity pre-planned attacks on targets of "political significance", such as the Secret Police (KHAD) offices and persons known for collaboration with the occupying forces.

ii. The Soviet-Kabul forces almost always hit back (when attacked) by way of reprisals by air force. This is particularly noticeable in

The author wishes to acknowledge the assistance provided by the Institute of Policy Studies, Islamabad, in the preparation of this part of the monthly report. 
the southern and eastern provinces. In the northern provinces bordering the Soviet Central Asia they are using both ground and air forces in coordination against civilian population suspected to be sympathetic to the Mujahideen.

\section{Saur Revolution celebrations disturbed}

Mujahideen carried out a series of operations coinciding with the "Saur Revolution" anniversary on April 27. Official celebrations in the capital and provinces were disturbed. The programmes held within the comparative safety of the Governor Houses in Parwan, Balkh and Qandahar had to be wounded up in haste. Similar functions in Sharin, Urgoon, Mazar, Khulm, Shigal, Shene Ghundi, and Aibak were also disturbed. Incidents on 27th April were also reported from Kabul and Takhar.

\section{Inter and Intra party rivalries}

It is interesting that some of the bomb blasts in Kabul and other cities, as well as incidents leading to disruption of important visits and celebrations are being attributed to bad blood and rivalries within the ruling party. It is well known that the supporters of Babrak Karmal have not taken kindly to his removal and conversion into a "nonperson".

\section{Defections}

An entire unit mutined near Kabul and joined Mujahideen after killing their officers in the first half of May.

Earlier, on April 28, some 600 Afghan troops had joined Mujahideen ranks in Maiwand, Qandahar province.

10 soldiers from Zazi cantonment laid down arms before Mujahideen on May 11. 38 conscripts switched to the Mujahideen side from Halangi Payan camp near Zazi on May 15. They brought along a Khad official as prisoner. Other reports stated that 42 Afghan troops joined the Mujahideen after killing the commander and Deputy of Bayan Khel post. Sizeable defections took place in Helmand, Zabul, Baghlan, Jozjan and Faryab.

\section{Safety Measures}

Presumably in order to blunt frequent Mujahideen rocket attacks on airports, the Kabul regime is constructing under ground 'hangers' in Qandahar and Herat.

Notable air losses

According to reports received from all parts of Afghanistan in 
May 1987, 40 aircraft and 31 helicopters were destroyed or damaged. 3 Soviet built helicopters were destroyed at the Qandahar airport on April 22. Another two Soviet built helicopters were destroyed as they collided while avoiding Mujahideen AA fire in Qalat, Zabul. See section 3 for details of such losses particularly in Qandahar, Paktiya, Ningarhar, Balkh and Kabul*.

\section{Khad Offices}

Mujahideen attacked Khad Office in Qandahar on May 10 and captured 7 Secret Service agents. Earlier on April 27, Mujahideen disturbed a Saur Revolution ceremony in the same building. Khad Chief of Takhar province as well as $6 \mathrm{Khad}$ men in Charikar (Parwan) were shot dead by Mujahideen.

\section{Political targets}

A brother of the Governor of Qandahar was shot dead by Mujahideen on May 17. Mujahideen attacked the regime administrative offices in Zairat, Paktiya. Mujahideen attacked the party offices in Asmar, Kunar in Mid April. 5 pylons at the power plant at Sarobi were destroyed by Mujahideen on May 1.8 office bearers of PDPA were killed in Doab, Laghman.

Highway blocked: Mujahideen operations caused suspension of traffic at the following places:

(i) On Kabul-Jalalabad highway for 2 days.

(ii) On Pule Khumri-Mazar Highway, Tangi Shorgan for 1 day.

(iii) On the Salang highway, a number of times.

\section{Northern Provinces}

While Soviet-Kabul forces continued retaliatory operations, the Mujahideen strategy was to cause dents in the security belts that were established during last 2 months in the Northern Provinces of Afghanistan.

Radio Kabul, it seems, is slightly increasing its war coverage. On May 31 it aired news in an unprecedented manner, reporting in detail that "the country's security forces resorting to brave action, discovered 11 depots of arms and ammunition belonging to opposition groups in Sarobi, Kabul province. These are considered to be the largest dumps of the enemies who intended to use them in Kabul and surrounding areas. It consisted of $1500 \mathrm{~S}-\mathrm{S}$ rockets, together with 1500 warheads, 1100 mines, $600 \mathrm{~kg}$ of explosives, 700 cartons of shells etc".

*This includes 26 aircrafts, 21 helicopters, destroyed/damaged in April but reported and incorporated in May. 


\section{2 - MAJOR MILITARY ENGAGEMENTS}

\section{Provinces Bordering Pakistan}

Qandahar witnessing intense fighting

In a series of attacks Mujahideen operated against security posts within and outside Qandahar city among other things destroying an arms depot. Mujahideen were also active in Charbagh area. Mujahideen conducted missile attacks on Qandahar cantonment and Qandahar airport. 50 Soviet-Kabul troops were killed or injured and 2 bunkers destroyed in the cantonment. 15 officials attending a meeting in Maiwand were killed. Mujahideen captured Aurang Military camp near Spinbuldak.

Meanwhile, Soviet-Kabul forces continued airstrikes in and around Arghandab and Qandahar city. On April 15, Soviet-Kabul troops set up post in Nazarjan Bagh, Durahi and Mirwan areas. A heavy Soviet-Kabul contingent of about 200 vehicles was deployed in Charbagh to deal with Mujahideen who had been attacking Soviet-Kabul convoys. The force surrounded a six $\mathrm{km}$ area.

\section{Extensive air raids on Paktiya}

Soviet-Kabul jets conducted punitive strikes on Mujahideen positions from where they had been attacking Zazi garrison. Mujahideen supplies carried on horse-back become target of air attacks in Paktiya. Mujahideen suffered casualties beside heavy loss of arms and ammunition. Heavy bombing was conducted against Mujahideen Jihadwal base in Paktiya. Mujahideen continued to strengthen their control on Sanakai front. They attacked Soviet-Kabul troops at Zazi, Mian Khel as well as Chamkani and Khost cantonments beside Soviet-Kabul contingent in Ali Sher area. Mujahideen captured some 50 Kabul troops near Khost. A Soviet-Kabul contingent carrying arms and food supplies set out from Gardez in early May for various cantonments of Paktiya province.

Mujahideen belonging to Hilmand and Qandahar provinces launched attacks on security posts in Lashkargah (Hilmand) inflicting losses to Soviet-Kabul forces.

\section{Attacks on Zama and Sharna (Paktika)}

Mujahideen launched attacks on Zama army camp in early May. In wake of these attacks 5 Afghan officers made their way to join Mujahideen. Mujahideen conducted many attacks on Sharna inflicting damage to 4 security posts. Mujahideen conducted several attacks on Asmar cantonment and damaged 2 buildings. Likewise, they destroyed a 
number of vehicles when a convoy was attacked between Shigal and Dandoona.

Ningarhar

Mujahideen embushed an armoured unit of Soviet-Kabul troops near Mahi Pir tunnel. As several vehicles were destroyed in this action, traffic remained suspended for 2 days between Kabul and Jalalabad.

Mujahideen struck various posts around Ghani Khel, Achin, Mohmand Dara, Chapparhar, Mama Khel in Ningarhar province.

\section{Provinces along Soviet Borders}

Soviet-Kabul troops launched an attack on Mujahideen in Kishm, Badakhshan. Mujahideen resistance inflicted heavy losses to the attacking troops. Soviet-Kabul troops attempt to set up some security posts in Urgu, Badakhshan was foiled by Mujahideen.

\section{Takhar}

Mujahideen struck security posts at Qarya Gul. Soviet-Kabul troops attempted to block the route between Rustaq and Yangi-Qila. Heavy bombing caused severe civilian losses. In late April a SovietKabul forces encircled Mujahideen positions in Rustaq forcing them to withdraw after being engaged in several fierce clashes. Mujahideen conducted attacks on Sarai-Sang, Qalbars and Khas Chapper.

\section{Mujahideen Operations in Baghlan}

Mujahideen conducted successful operations against six security posts near Baghlan Industrial area. These posts had been set up in late March in order to drive Mujahideen out of the area. In Naqsh and Pul-eKhumri areas Mujahideen raided security posts.

\section{Convoy Attacked}

Mujahideen attacked a convoy in Qalazal on May 4 and another on May 8 at Eidgah in Baghlan province.

\section{Punitive Bombing}

Heavy bombardment of civilian areas in Samangan province forced a large number of civilians to flee their hearths and homes. Later, in the 2nd week of May, the Mujahideen carried out joint operation to wipe out 7 posts guarding the gas supply lines in Andkhoi, Samangan. 


\section{Provinces along Iranian Borders}

Soviet-Kabul Operations

Soviet-Kabul forces made a surprise attack on Mujahideen base close to Soviet-Iranian border in Herat province. The force earlier ambushed a Mujahideen column in Ghurian district.

\section{Central Provinces}

\section{Siege}

Mujahideen continued their siege of Shehrak town in Ghor province for the second month running. They are believed to have captured sizeable quantities of arms and ammunition in this area.

\section{Capital and Parwan}

\section{Severe Air Losses}

Mujahideen took a heavy toll of Soviet-Kabul aircraft in Kabul province, where they hit 8 aeroplanes and 5 helicopters.

\section{Soviet-Kabul Offensive Frustrated}

Mujahideen repulsed a big offensive in Sarobi district after inflicting heavy losses to Soviet-Kabul troops.

\section{Mujahideen Operations}

Mujahideen ambushed a military convoy at Sarai Khawaja. Mujahideen attacked Soviet-Kabul post and positions at Chakri, Bagrami, Paghman, Qargha, Kohe Safi.

\section{Parwan}

Mujahideen conducted a number of attacks on troops/convoys at various points of Salang valley, the highway between Jablus Siraj and Salang tunnel, in and around Charikar, and at the Qila Surkh military camp etc.

\section{3- PROVINCEWISE SURVEY ANALYSIS}

\section{Provinces Bordering Pakistan}

Nimruz (also bordering Iran)

Mujahideen sources: Mujahideen attacked the sub-divisional headquarters at Khash Rod on May 12, killing 9 Soviet-Kabul troops. A 
military barrack was set on fire. Mujahideen withdrew on arrival of regime reinforcements.

VOA: Another important guerilla commander was killed on May 10 th in the South Western province of Nimruz in an ambush. The report quotes a resistance spokesman as saying the Mujahideen fighters fought for 3 hours and killed 10 soldiers, but lost their commander in battle (News-English: 22 May, 1987).

Radio Kabul: With the cooperation of the local people and timely action of the security forces another criminal plan of the extremist forces was exposed and foiled in Shatak area of Lalander. The Security Forces, by observing ceasefire, entered the Shatak area and seized three ground-to-ground missiles and nine mortar shells of the extremist elements. The extremists had wanted to create a wave of terror and fear among our noble people (News-Pushto: 20 May, 1987).

In response to the National Reconciliation Policy of the Afghan Government more than 75 families of our countrymen have returned to their homes in Ningarhar, Herat and Nimruz provinces via Torkham and Islamqala border posts (News-Pushto: 11 May, 1987).

\section{Hilmand}

Mujahideen sources: Mujahideen shot down a helicopter bombarding their posts in Grishk sub-division on 1 May. The helicopter was hit with a missile.

\section{Qandahar}

Mujahideen sources: 9 April: Fifty Soviet-Kabul troops killed in a surprise attack on security posts in Charbagh area. An aircraft downed.

13 April: Soviets jets bombard Mujahideen positions in Arghandab district. One of the aircraft is hit and then crashes.

17 April: About 40 regime officers and men captured during a series of attacks on Soviet-Kabul troops in Charbagh area. A number of Soviet-Kabul soldiers killed.

19 April: "Russians" encircled the area between Sarpoza and the tomb of Mirwaiz Neka and bulldozed all orchards and inns in an area of 6 kilometres. During the operation the Russians killed 13 civilians and injured 16 others near the Zaher Shahi Canal.

20 April: A Soviet-Kabul force of about 200 tanks and other vehicles appeared in Charbagh to attack Mujahideen positions. Sixteen Russians and 7 Kabuli officers and men were killed. Four tanks destroyed. Eight government soldiers surrendered to Mujahideen. fire.

A MiG jet was knocked down in Charbagh area by anti-aircraft gun 
22 April: In a surprise attack on Qandahar airport Mujahideen destroyed a jet fighter, a helicopter and 3 tanks. The Soviets are constructing underground hangers at Qandahar airport.

24 April: Mujahideen attacked a mobile Soviet-Kabul force in Pashtun Bagh area, destroying a tank and two trucks.

27 April: Mujahideen fired rockets at Khad headquarters in Qandahar where they were reportedly "celebrating the Saur Revolution". Some members of Khad organisation were killed.

28 April: Six hundred government troops defected and joined Mujahideen in Mainwand sub-division.

Mujahideen captured a military camp at Aurang near Spinbuldak on Pak-Afghan border. Soviet-Kabul troops suffered 30 casualties and Mujahideen 22 in the fighting which lasted 4 hours. Mujahideen also seized a quantity of arms and ammunition from the camp.

Mujahideen attacked the Qandahar airport as a result of which 3 parked helicopters were destroyed. A number of 'Soviets' were also killed.

29 April: Fifty Soviet-Kabul troops were killed or injured in BM12 missiles attacks on Qandahar cantonment.

30 April: Mujahideen wipe out two Soviet-Kabul security posts near Spinbuldak.

1 May: Mujahideen attacked a security post at Eidgah gate of Qandahar city. Eight troops were killed and an armoured car destroyed.

6 May: Fifteen 'officials', including Parcham and Khalq officebearers, were killed during a Mujahideen attack on an "official building" in Maiwand area.

8 May: Mohammad Aman, a member of the National Reconciliation Commission, was killed by Mujahideen inside the city. Mohammad was the brother of the governor of Qandahar.

10 May: Mujahideen attacked the Khad office in Qandahar city and captured Khad agents.

11 May: A helicopter bombarding Mujahideen positions in Nari near Spinbuldak was shot down.

12 May: Mujahideen ambushed an armoured unit near Arghandab township. A tank was destroyed. While the force was retreating Soviet helicopters hit back killing 2 and injuring 7 Mujahideen.

VOIR: On Hamal 16, the library of the Marxist books near Qandahar cinema was set on fire by the Muslim Freedom Fighters. On the following day the Muslim Freedom Fighters in a clash with the SovietKabul troops in Haji Nazar Jan area destroyed 5 tanks of the Soviets. In another attack the Mujahideen destroyed a military post of the Russians in Kalache area. In this operation one tank of the enemy was 
set ablaze and 6 personnel of the puppet regime posted there were killed (News-Pushto: 4 May, 1987).

Mujahideen attacked a military post of the Soviet-Kabul troops in Qandahar as a result of which 8 Soviet-Kabul troops were killed (17 May, 1987).

Fifteen Communist troops were killed during Mujahideen attacks on Soviet-Kabul security posts in Qandahar (21 May, 1987).

Radio Tehran: A military post of the Soviet-Kabul troops in Qandahar province was attacked by the Afghan Mujahideen as a result of which 12 Soviet-Kabul troops were killed and 3 Soviet armoured personnel carriers were destroyed. Fifty-five Kabuli troops joined the ranks of the Afghan Mujahideen (News-Persian: 2 May, 1987).

In an attack on a building of the Kabul regime in Maiwand area of Qandahar province, at least 15 Soviet-Kabul troops were killed by Afghan Mujahideen (23 May, 1987).

VOA: Afghan Mujahideen commanders say that Soviet-led forces are planning to attack Mujahideen positions near Qandahar. They said that preparations have been made in Qandahar and large quantities of weapons have been gathered. They said that Afghan Defence Minister, General Muhammad Rafi is personally supervising the military preparations (News-Urdu: 20 May, 1987).

Resistance sources say that as many as 16 Soviet-made bombers participated in a raid on villages around Qandahar. The sources say 80 civilians were killed and 120 wounded in the attack (22 May, 1987).

Reports have been received that Soviet and Afghan government troops have launched a big offensive against Mujahideen near Qandahar, the second largest city of Afghanistan. VOA's correspondent Allan Pessin reports from Islamabad that the Mujahideen had been expecting this attack for over a week.

According to reports from the war-field and the injured reaching Pakistan on Wednesday, the offensive began in the north of Qandahar on Tuesday. The sources say the Soviet and Afghan troops carried out air and artillery attacks on Mujahideen positions. The Mujahideen sources say that a large number of Soviet and Afghan troops were killed during advance towards Mujahideen strongholds. They also say that a number of Afghan troops had defected to them. The sources further say that correct number of those killed on both sides could not be ascertained as the fighting is quite intensive and has spread over a large area. The Mujahideen sources say they expect that the fighting would spread upto Mujahideen's positions in west and south of the city in the next few weeks ... Last week, the Mujahideen had reported that 6,000 Soviet and Afghan troops had entered Qandahar in connection with 
preparations for the attack. Informed sources in Qandahar and Pakistan say that in view of the offensive, thousands of people have fled to Pakistan, and villages near Qandahar are giving a deserted look (Radio Report: Urdu: 29 May, 1987).

According to a radio message received in Pakistan, an Afghan resistance commander says that the Mujahideen have turned back a major offensive by Soviet and Afghan forces near Qandahar city (News English: 31 May 1987).

Radio Kabul: The High Commission of the National Reconciliation has reported that the extremist elements have committed another unpardonable crime in Qandahar. The extremist elements martyred the Chairman of the National Reconciliation Commission of Qandahar city on Friday. Bakhtar correspondent has reported that his funeral was attended by the Party and Government officials and a large number of citizens of Qandahar city (News-Pushto: 10 May, 1987).

The enemies of the sacred religion of Islam committed another heinous crime in Qandahar city by attacking and martyring the Imam of the Khirqa Mubarak of the Holy Prophet (peace be upon him). This exposed once again their inhuman and anti-Islamic face. As our compatriots are aware, on Saur 27 which coincided with the 19th of Ramazan, a number of criminals attacked the Khirqa Mubarak of the Holy Prophet (peace be upon him) in Qandahar city, martyring the Imam of the Jamia Mosque of Khirqa Sharif, Mohammad Nabi, who was busy in the call for prayers (Azan) and damaged the Ziarat of the Mubarak Khirqa (News-Pushto: 22 May, 1987).

A group of 75 families, comprising 125 persons have returned to their homes in various localities of Qandahar province. These people have started living a peaceful life with their relatives (24 May, 1987).

Radio Moscow: Reports have come in about another crime committed by the Counter-Revolutionaries in Afghanistan. On the 17th of this month a group of bandits made their way into a mosque in one of the districts of the city of Qandahar and killed Imam Mohammad Nabi. The religious leader was known for his support for the policy of National Reconciliation (News-English: 22 May, 1987).

\section{Zabul}

Mujahideen sources: On April 25, Mujahideen attacked a SovietKabul convoy in Shahjoi district of Zabul province destroying 3 tanks and killing 27 soldiers.

Two Soviet-made helicopters were seen colliding and being destroyed near the Qalat Ghilzai (provincial headquarters) airport on April 30 . 
Eight Kabul Government soldiers stationed in a suburb of Qalat Ghilzai defected and joined the Mujahideen on May 1.

Mujahideen dynamited a security post in Atghar sub-division on May 9. A number of Kabul soldiers were killed. Mujahideen captured 22 rifles, a mortar gun and a jeep.

According to another report received on May 17, Mujahideen attacked the Shah Joi sub-divisional headquarters located along the Kabul-Qandahar highway. Some administrative and military buildings were hit by rocket fire.

VOIR: Soviet-Kabul troops came under rocket attack of Mujahideen in Kalatezai area, as a result of which 17 communists were killed and the convoy was compelled to retreat (News-Pushto: 14 May 1987).

Radio Tehran: Afghan Mujahideen attacked a military convoy of the Soviet-Afghan troops and 18 Soviet-Kabul troops were killed (News -Persian: 10 May, 1987).

Radio Kabul: An evil plan of the counter-revolutionary terrorists to fire US-made ground-to-ground missiles on Kalat city of Zabul province was foiled with the cooperation of the toiling people of the area. The security forces entered the area, on the advice of the National Reconciliation Commission of Zabul province, and seized 7 missiles (News-Pushto: 19 May, 1987).

\section{Ghazni}

Mujahideen sources: 17 April: Mujahideen hit a helicopter in a suburb of Ghazni city.

22 April: Mujahideen shelled Ghazni airport, destroying some barracks and bunkers.

24 April: A tank of a Soviet-Kabul mobile force was destroyed (evidently) near Ghazni city.

26 April: Two troopers captured during an attack on a security post near Sabzdari.

On May 21, a Soviet armoured unit was sent out to attack Mujahideen strongholds in Khawaja Hakeem, a suburb of Ghazni. It was mistakenly taken as 'Mujahideen' by Kabuli troops manning a security post. The Kabulis fired rockets on the Russians who fired back. A Soviet tank and some officers and men were killed during the exchanges.

Mujahideen attacked a military convoy near Qara Bagh on KabulQandahar Highway on May 3. The battle continued for over 4 hours after which the convoy broke off leaving behind wreckage of 3 armoured vehicles and a truck as well as 15 dead bodies. The Mujahideen captured a jeep, a wireless set and 16 rifles. 


\section{Paktika}

Mujahideen sources: 19 April: Mujahideen attack security posts around Urgoon cantonment.

22 April: A tank and 2 army vehicles destroyed near Katwaz. They also attack tehsil headquarters of Mata Khan.

27-28 April: Mujahideen wipe out a security post at Jami Milli near Urgoon town.

In early May, Mujahideen conducted a series of attacks on SovietKabul military camp at Zama in Urgoon sub-division province. On May 4 they fired rockets at Zama killing 5 troops and destroying a jeep. On the following day they hit a tank and another vehicle proceeding towards Urgoon. In another operation they destroyed an army vehicle.

\section{Paktiya}

Mujahideen sources: 15 April: Mujahideen knock down a jet near Mughulgai.

16 April: Another jet downed in Zazi Maidan.

19 April: A tank destroyed at the security post of Senakai.

24 April: Mujahideen destroyed a tank and a jeep at Mian Khan near Zazi cantonment.

26 April: Mujahideen fired rockets at Chamkani and Khost cantonments.

29 April: An MI-25 shot down near Gardez.

2 May: A Soviet aircraft hit by Mujahideen anti-aircraft guns near Khost city. Mujahideen attacked and killed 4 Soviet-Kabul troops in Ali Sher area.

3 May: A Soviet-Kabul force moved out from Khost and proceeded towards Ghulam Khan (Pak-Afghan border area). It was attacked and fifty soldiers captured.

4 May: Mujahideen attacked a military camp at Khair Kot: A tank and two other vehicles smashed by rocket and mortar fire.

5 May: Mujahideen attacked security posts of Alam Khan and Pashusi. Mujahideen fired ground-to-ground rockets on military garrison in Zazi cantonment.

Two jet fighters bombarded Mujahideen positions surrounding Zazi cantonment. One of the aircraft was hit by surface-to-air rockets.

(The same report said that 'recently' ... ) Eight Soviet aircraft attacked a Mujahideen convoy carrying arms and ammunition (probably in the same area). As a result 60 horses carrying supplies were killed and the arms and ammunition and other articles lost. Eleven Mujahideen either killed or injured).

11 May: Ten Kabul Government soldiers belonging to Zazi garri- 
son surrendered to Mujahideen.

(The report said Mujahideen commanders perceived that "Russians" were preparing to mount a big operation against Mujahideen strongholds in the vicinity of Zazi on Pakistan-Afghanistan border).

16 May: Mujahideen fired rockets on security posts protecting Zazi cantonment. Soviet-Kabul troops suffered heavy casualties. Mujahideen lost their commander (Abdul Aziz).

Forty Afghan soldiers joined Mujahideen ranks after killing their commander. They arrived in two trucks alongwith a quantity of arms and ammunition. They had belonged to the Bayan Khel security post.

17 May: Soviet plans bombarded the Jehad Wal centre of Mujahideen south of Khost cantonment. Two Mujahideen and 3 captured Afghan Government soldiers were injured.

18 May: A MI-24 helicopter bombarding Mujahideen positions near Hashim Khel village in Zazi district shot down.

VOIR: Mujahideen attacked Soviet-Kabul troops in Khost and Chamkani areas. Twelve enemy troops were killed and a number of others were injured (10 May, 1987).

Radio Tehran: An aircraft of Kabul regime was shot down in Zazi area of Paktia province a few days ago (2 May, 1987).

During an operation in Paktia, the Muslim Revolutionaries have destroyed a tank and killed 3 soldiers (17 May, 1987).

A helicopter of the Kabul regime, which planned to hit the strongholds of Muslim Revolutionaries in Hassan Khel area of Zazi was downed by anti-aircraft guns. Thirty-eight soldiers of Kabul regime joined the ranks of the Mulsim Revolutionaries (23 May, 1987).

Radio Kabul: According to a report reaching Bakhtar News Agency, a press conference was held in the Jirga Hall of Nationalities and Tribes in Khost in connection with condemnation of border violations and attacks on Afghan passenger plane by Pakistan. The press conference was attended by local and foreign journalists. These journalists also saw wreckage of Afghan passenger plane shot down with Stinger missile recently. Later, in a military garrison located in Salahuddin village of the same district, a US Sidewinder missile was shown on behalf of Corp Commander of the area. This missile was fired at a defence post of Afghanistan some days ago, but did not explode (News-Urdu: 9 May, 1987).

About 1,300 families of the Kochi subtribes of Musa Khel, Issa Khel, Patane, Sulaiman Khel, Mainzai and Sulaimanzai, have returned to their homeland in Paktia province ... The Pakistan Government is obstructing the return of our Kochi brothers. The report said that as a result of the clash which took place between the elements of an ex- 
tremists group and the intending returnees of the Musa Khel Kochi tribe, 13 extremists were killed and 3 youths of the Musa Khel tribe were also martyred. Similarly, a large number of cattle of the Kochis were looted by the extremist elements (News-Pushto: 12 May, 1987).

\section{Ningarhar}

Mujahideen sources: 26 April: Eleven Mujahideen were killed in a mine-field laid by "Russians" in a gorge (called Zeran) in Pachir subdivision of Khugiani district.

(The Soviet had carried out a sizeable operation in Nazian and Khugiani district of Ningarhar in later part of April. While returning to their bases the Russians laid landmines to obstruct communications of Mujahideen).

13 May: Four militiamen were killed and 7 wounded during a Mujahideen attack on Mamkhel in Khugiani district. Mujahideen used $75 \mathrm{~mm}$ guns, mortars and ground-to-ground rockets.

14 May: Mujahideen ambushed a military convoy at Mahi Per, 60 kilometres from Jalalabad. The convoy returned to Kabul. Fifty Kabul Government troops were captured and 4 vehicles destroyed.

15 May: Mujahideen wiped out two security posts in Mahmand Dara area. Ammunition and fuel dumps were blasted and a military vehicle destroyed. These security posts had lately been set up.

VOIR: In fierce fighting in Ningarhar province lasting for two days, two Soviet fighter planes and 5 helicopters were shot down by Mujahideen. Fifty communist troops were killed and 25 captured (9 May, 1987).

VOA: Diplomatic sources have confirmed that the Soviet-led attack on Mujahideen positions in Ningarhar province near Pakistan border in April last was successfully repulsed. The sources say Mujahideen killed scores of Soviet troops and captured 28 others. Afghan Mujahideen also shot down two helicopters and two jet planes after firing missiles on April 21 and 22 (6 May, 1987).

\section{Kunar}

Mujahideen sources: 20 April: Mujahideen attacked Asmar with ground-to-ground rockets. Two buildings were destroyed.

26 April: A SÜ-25 was knocked down in Asmar.

27 April: Twenty-eight Soviet-Kabul troops were killed during a series of attacks on Soviet-Kabul security posts in Shegal area.

Ten Soviet-Kabul troops were killed in Shene Ghondee area. A Soviet-Kabul convoy was attacked while it was on its way from Jalalabad to Asadabad. Two APCs were destroyed and 5 'Russians' killed. 
13 May: Mujahideen attacked a security post in Khas Kunar district, killing two militiamen.

VOIR: Afghan Mujahideen launched an attack on the positions of Soviet-Kabul troops in Asmar area a few days ago. A number of SovietKabul troops were killed and 4 Soviet tanks were destroyed (NewsPersian: 9 May, 1987).

$V O A$ : Western diplomats have confirmed Mujahideen claims that they had besieged Asadabad, the provincial capital of Kunar (6 May, 1987).

\section{Provinces Bordering Soviet Union}

Badakhshan (also bordering Pakistan)

Mujahideen sources: Soviet forces entered the liberated area of Urgu near a projection of territory where Soviet, Chinese, Pakistani and Afghan frontiers meet. There they tried to set up security posts. The Mujahideen hit back inflicting heavy losses on the invaders. Six Mujahideen were also killed and 23 others wounded in the fighting. While retreating on April 21 the Soviets left behind wreckage of two tanks.

$V O A$ : Heavy fighting is continuing between Afghan troops and Mujahideen in the eastern and northern parts of Afghanistan. Here is a despatch from Irfan Ghazi:

Quoting Afghans who arrived in Kabul from northern Afghanistan, diplomatic sources in Islamabad say that large scale destruction was carried out by Soviet forces in Badakhshan and Kunduz provinces. This action is being taken in retaliation to recent cross-border attacks on adjoining Soviet territories (6 May, 1987).

\section{Takhar}

Mujahideen sources: Soviet-Kabul troops continued their ground as well as air attacks against Mujahideen positions and civilian areas in Takhar during the months of April and May. The attacking planes normally take off from Soviet territories. More than 300 civilians are reported to have been killed in these attacks. Fruit gardens and standing crops have also been destroyed. The Mujahideen have withdrawn from some of these areas under heavy enemy pressure. Some Mujahideen have also been captured. However, on April 27, Mujahideen repulsed a heavy Soviet-Kabul attack in the Rosnak sub-division. Counter attacking, the Mujahideen killed 10 militiamen and a Khad official. They also captured some arms. In other attacks on intruding Soviet-Kabul troops in Sarai Sang, Qalbars and Khas Kappa areas, the Mujahideen killed or wounded a large number of soldiers.

Radio Tehran: The Afghan Muslim revolutionaries have inflicted 
heavy losses on Kabul as well as Soviet occupation troops during fierce fighting in the Takhar province (5 May, 1987).

Radio Kabul: In response to the National Reconciliation Programme another 8 families of our compatriots returned to their homes in Badghis, Baghlan and Takhar provinces yesterday (News-Pushto: 20 May, 1987).

Radio Moscow: Tired of long years of fratricidal war 150 men have laid down their arms and joined the process of National Reconciliation in Takhar province (14 May, 1987).

\section{Kunduz}

Mujahideen sources: On May 3, a "Russian" convoy was attacked by the Mujahideen near Qala-e-Zal. Five tanks, two military trucks and one telecommunication vehicle were eliminated. Seven Mujahideen were also killed and 17 wounded in the fighting.

On May 4, Soviet aircraft bombarded the surrounding areas (of Qala-e-Zal).

On May 8, a Soviet convoy was attacked at Eidgah in the Dasht-eArchi district. In the engagement which lasted half an hour, two tanks were destroyed.

On May 9, two jet fighters and 4 helicopters bombarded villages around Eidgah, killing 4 women and old people and destroying some houses.

VOA: Western diplomats say Soviet-led forces continue to attack villages in northern Afghanistan in retaliation for recent Mujahideen raids inside Soviet territory. Diplomats say travellers arriving from the north report that Soviet and Afghan forces pound villages with artillery while aircraft simultaneously bombard them. They say damage has been extensive in Kunduz province (News-English: 5 May, 1987).

\section{Baghlan}

Mujahideen sources: Mujahideen attacked newly established security posts in the industrial estate of Baghlan city, Jandak Valley, and Akhtar and Khalazee villages during the second week of April. After fierce fighting beginning April 11, all the posts were captured. Four Soviet-Kabul tanks and 3 bulldozers were destroyed. Fifteen militiamen were killed and many others wounded. Mujahideen also captured two vehicles and a quantity of arms and ammunition.

On 17 April, Mujahideen attacked Soviet-Kabul security posts in the Naqsha, 3 kilometres from Baghlan city. Forty Soviet-Kabul soldiers were killed or wounded and 8 tanks destroyed.

Rahmatullah, a Kabul government militia commander joined the 
Mujahideen alongwith about 500 men in Baghlan province on 30 April. Rahmatullah's defection has resulted in considerable enhancement of Mujahideen strength in Baghlan. He also brought with him 3 tanks, one jeep and 1200 Klashinkovs.

Mujahideen captured $4 \mathrm{Kabul}$ Administration "officials" travelling in a jeep between Baghlan's Shehr-e-Jadid and the Sugar Factory. They were transferred to the Liberated Area on May 16.

On 17th May, Mujahideen killed 3 Kabul regime soldiers who had 'disguised themselves' as Mujahideen and were engaged in swindling the common people of their cash, watches and other valuables. They were stopping vehicles at a place 200 metres from Kabul Army security posts between roads number 10 and 11 near Pul-e-Khumri town. This obviously was an effort to discredit Mujahideen with the people.

The same day (17 May) ambushed a Soviet patrol in the Salang Valley killing a number of them.

VOIR: The Afghan Mujahideen have attacked and destroyed 5 military posts of Soviet-Kabul troops in Baghlan province. Fifteen enemy troops were killed and 4 tanks destroyed (3 May, 1987).

A commander of the Communist regime joined the Mujahideen alongwith 500 military personnel, 2 tanks, 1280 klashnikovs and a number of military vehicles. The commander had previously been in secret communication with Mujahideen (News-Pushto: 10 May, 1987).

Radio Tehran: Mujahideen destroyed a power house in Pul-eKhumri city and killed 8 communist troops (4 May, 1987).

$V O A$ : Diplomats say the Baghlan city has been "ruined" by shelling carried out by Afghan and Soviet troops last month as the city was under Mujahideen control.

Radio Moscow: Another 20 Afghans, who had in the past indulged in counter-revolutionary activities, have been pardoned in Baghlan province (24 May, 1987).

\section{Samangan}

Mujahideen sources: Mujahideen attacked a number of security posts near Khulam city and inflicted heavy losses on Soviet-Kabul troops. Soviet-Kabul forces replied by bombarding the nearby villages. About 1,000 local people had to flee their homes and seek shelter in the hills, a report received on 15 May said.

Mujahideen fired rockets on Aibak city on April 27, (Saur Revolution anniversary).

\section{Balkh}

Mujahideen sources: Mujahideen shot down two bombers and a 
reconnaissance plane on April 27. Mujahideen also disrupted the "Saur Revolution" ceremonies taking place in the Governor House by launching a daring rocket attack in Mazar-i-Sharif. Eight "officials" of the "puppet administration" were killed.

Soviet-Kabul troops conducted a powerful artillery and ground-toground rocket attack on villages in Sholgar district on 17 April, which lasted for twelve days. Over one hundred civilians were killed. Seven Mujahideen were also killed and 80 wounded. Soviet-Kabul losses included about 200 men, 4 tanks/trucks and one helicopter.

On April 28, Mujahideen intercepted a Soviet convoy near Mazar-iSharif. The convoy retreated leaving behind the wreckage of a tank.

On May 9, Mujahideen and Soviet-Kabul troops clashed (name of place not mentioned). Two APCs were destroyed. Two Mujahideen also killed.

Fifteen militiamen were killed and an APC was destroyed in Chamtal district on May 10.

Radio Tehran: The Muslim Afghan Revolutionaries attacked another military convoy of the Soviet troops near Mazar-i-Sharif and captured a large quantity of arms and ammunition. Nine Communist troops were killed and several injured (17 May, 1987).

Muslim Afghan Revolutionaries inflicted heavy blows on the Soviet and Afghan Government troops in Balkh province (News-Urdu: 23 May, 1987).

(Radio) Switzerland: The Soviet Union says Afghan guerillas have killed or wounded more than 20 people in a rocket attack in the Afghan town of Mazar-i-Sharif, near the Soviet border. The Soviet news agency TASS said the attack was staged during celebrations marking the 9th anniversary of the communist takeover in Afghanistan (NewsEnglish: 23 May, 1987).

Jozjan

Mujahideen sources: On May 5, Mujahideen attacked security posts near Shibbarghan, provincial headquarters of Jozjan. Five "Soviets" were killed.

In an interview with AIC correspondent Mujahideen commander in Jozjan described the military situation in the province as follows:

"Even though the Mujahideen have only limited military possibilities, they control most of the area in Jozjan. The Russians have their bases in Shiberghan, Dasht-e-Laila and Khwaja Birdak. The main Russian base is located in Dasht-e-Laila (the central part of the gas pipeline). There are 4,000 Russian families in Dasht-e-Laila.

"The local civilian population provides food to the Mujahideen. 
About 80 per cent of the resident of Jozjan still live in their villages. They cultivate land and breed animals.

"The Russians have been bombarding and burning standing and harvested crops. There were 4 dams in Jozjan which had irrigated a large area. The Russians have destroyed 3 of the dams, namely, Jigdalak, Zakra and Saidabad. ... Likewise, the regime has set up security posts on the canal Welayat Wiala and restricted the supply of irrigation water".

The commander said the Mujahideen in Jozjan suffer from shortage of medicines and 'heavy weapons'.

Asked about the former King Zahir Shah, the commander said, that a majority of the local population and the Mujahideen were in favour of Zahir Shah.

\section{Faryab}

Mujahideen sources: On May 10, Mujahideen in 'joint operations' (of various groups) carried out attacks on 'recently established' security posts in Andkhol district. Seven posts were run over and 30 militiamen killed. Fifty militiamen surrendered to Mujahideen who also captured arms and ammunition.

Radio Kabul: Extremist elements who are against tranquility and prosperity of our compatriots fired mortar shells on Maimana city, the capital of Faryab province, on Friday evening. They fired 5 mortar shells on the city which resulted in killing and wounding of many people, including women and children (News-English: 19 May, 1987).

Radio Moscow: In Afghanistan more of the armed groups are going over to the side of the People's Government despite attempts of the counter-revolutionaries to undermine the process of National Reconciliation. In the past few days, 600 former band members ended resistance in the provinces of Faryab, Farah and Khairabad district of Kabul province (News-English: 18 May, 1987).

\section{Badghis}

Mujahideen sources: On April 28, Mujahideen ambushed a group of "Russian" soldiers carrying water to their base area of Qala-e-Gaz in Central Badghis. Seven Russians were killed. Mujahideen captured a jeep and 7 kalakovs.

The Soviets retaliated by bombarding villages of Shaeikh Thana, killing or injuring 10 civilians. Two Mujahideen were also killed.

A report received on 5 May said that "recently" Mujahideen had broken out of "enemy siege" (somewhere) in Badghis province. Fiftysix Soviet-Kabul troops were killed. 


\section{Provinces Bordering Iran}

Herat (also bordering Soviet Union)

Mujahideen sources: 22 April: Mujahideen ambush a Soviet-Kabul convoy in Shehr-e-Nau. Three tanks and 5 armoured vehicles destroyed.

Soviet-Kabul aircraft attack Mujahideen positions, killing 7 and injuring 22 Mujahideen.

26 April: Mujahideen fire rockets on a security posts in the 'central area' of Herat city, hitting an APC. Mujahideen capture a vehicle, 2 mortar guns and some other arms and ammunition.

1 May: Mujahideen wipe security posts at Dakka, Kabooter Khan, Shah Ghalian and Qabarzan in Injeel sub-division. At least 20 SovietKabul soldiers killed. Other fled.

3 May: In heavy bombardment on rural communities in Injeel subdivision Soviet-Kabul aircraft killed 81 civilians. More than 120 injured. Most the killed and injured were women and children. Eighteen living houses destroyed.

VOIR: Two Soviet aircrafts were shot down by Afghan Mujahideen in Herat and Paktia provinces during the last few days ( 3 May, 1987).

As a result of indiscriminate bombardment of the residential areas of Ghorian three days back, 81 persons were martyred and 110 others were injured. In this aerial action 14 Soviet fighter planes took part.

The aerial raids of the enemy took place shortly after successful attacks of the Muslim Mujahideen on new military posts of the Soviets. During these operations more than 20 government troops were killed (News-Pushto: 10 May, 1987).

Mujahideen attacked a caravan of the communist troops in Herat province and inflicted heavy losses on them in men and material. The communist troops were compelled to retreat (News-Pushto: 24 May, 1987).

Radio Tehran: Following successful operations of Afghan Muslim Revolutionaries in Herat last month, fighter planes of Kabul government carried out barbaric attacks on the Injeel area of Herat province. As a result of these attacks 81 persons were martyred and 18 houses were destroyed (10 May, 1987).

VOA: In northwestern Afghanistan resistance commanders say their forces had downed a Soviet-made helicopter in Herat province, 15 kilometres from the Soviet border (News-English: 1 May, 1987).

According to resistance sources intense fighting took place at several places in the northwestern province of Herat during this month. The sources say Soviet-led Afghan forces staged a surprise raid, May 
12th, on a Mujahideen base only a few kilometres from the Iranian and Soviet borders. The reports say 22 Mujahideen fighters including the base commander were killed and an unspecified number were captured. Earlier in the Ghorian district government troops ambushed a guerilla column. Sources say 5 members of the Mujahideen column including a commander were killed.

The sources say resistance forces appeared better placed in the interior of the province. Mujahideen raided 6 villages of South West of Herat city on May 8, killing 20 militiamen.

The Mujahideen guerillas ambushed a militia convoy, May 12th, about 40 kilometres west of Herat city. Thirty-four government soldiers were killed and a large number of weapons captured. The reports say that an important militia commander was among those killed (22 May, 1987).

Radio Kabul: The process of return of Afghans to their homeland is continuing and 1,828 people have returned to Herat from Iran (News-Pushto: 17 May, 1987).

Farah

Mujahideen sources: The Mujahideen on May 8 destroyed a tank and two transport vehicles of a Soviet convoy in Farah Rud area of Farah province. The convoy was advancing towards the Soviet base of Shindand. The convoy retreated.

Radio Tehran: An aircraft of the Kabul regime which intended to bombard the positions of Afghan Mujahideen in Farah province was shot down (2 May, 1987).

A military convoy of the Soviet-Kabul troops was attacked by Afghan Mujahideen in Farah Rud area of Farah province. Reports said that the convoy which was proceeding towards Shindand military base was forced to retreat after suffering casualties and loss of one tank and a military truck (News-Persian: 25 May, 1987).

\section{Central Provinces}

\section{Bamiyan}

Mujahideen sources: A Soviet helicopter was shot down on May 12 while it was carrying supplies to besieged troops in Bamiyan cantonment.

\section{Ghor}

Mujahideen sources: Nil report reported by Agency (27 May, 87). 


\section{Uruzgan}

Mujahideen sources: Between April 19 and May 2, Mujahideen carried out "joint" attacks on targets in Uruzgan province, killing at least 77 officers and men of the Soviet-Kabul troops. The Mujahideen shot down 3 helicopters. About 70 Mujahideen and civilians were killed during the fighting.

\section{Kabul and Adjacent Provinces}

\section{Kabul}

Mujahideen sources: 12 April: Two fighters and a helicopter shot down in Koh-e-Safi and Dehsabz areas.

15 April: A helicopter shot down in Koh-i-Safi area. Mujahideen attack a convoy carrying petroleum products in Sarai-Khawaja district. Five tankers destroyed.

17 April: Two Soviet-Kabul APCs destroyed in Mir Bachakot district.

19 April: A helicopter shot down in Sarobi district.

20 April: Mujahideen repulse a big Soviet-Kabul attack in Saroobi district. A jet fighter shot down in southeast part of Kabul city.

26 April: Mujahideen fire rockets in Koh-i-Safi area.

29 April: Three regime soldiers killed and a tank destroyed during a Mujahideen attack on "Jackson" security post in Paghman subdivision.

1 May: Five electric pylons destroy during Mujahideen attack on Saroobi Power Plant. Soviet-Kabul lost 8 and Mujahideen 3 during Mujahideen attack on a security post in Arghand.

2 May: (In retaliation) Saboori, Jigdalak and Mane Chakhai were bombarded by Soviet aircraft. A military vehicle destroyed by bomb blast near Kabul airport. Three Soviet aircrafts were hit and destroyed by rockets in the Mandikhel valley in Koh-e-Safi.

4 May: The Soviets responded by sending forth a combined SovietKabul land force to the Mandikhel valley. In the encounter 15 regime and 5 Mujahideen fighters were killed.

The Soviet-Kabul force returned to Kabul in the evening after planting anti-personnel mines in the area. The mines killed 4 Mujahideen and injured 5 others, including Mujahideen commander (Abdur Rauf). Seven civilians were also killed in the mine fields.

Two Soviet-Kabul columns arrive in Saroobi, via Chino and Lataband routes to curb Mujahideen activities in the area. The invading Soviet-Kabul force was supported by jet fighters, three of which were shot down near Jigdali and Mane Chakhe. Both sides suffered casualties 
including 6 dead among Mujahideen ranks.

Two KHAD agents were captured near Wazir Chahar and shifted to the Liberated Area alongwith the jeep they were travelling in.

VOIR: Muslim Mujahideen have shot down two Russian helicopters, one in Ainak area of Logar and the other in Bagram area of Kabul (14 May, 1987).

Mujahideen attacked Soviet-Kabul troops in Paghman Woleswali on the 9th of this month. Three Soviet troops were killed and a tank destroyed.

In another attack, 8 troops of Kabul regime were killed in Arghandoo area of Kabul. One Mujahid was martyred and two sustained injuries (17 May, 1987).

The President of the Party Committee of the Polytechnic Institute of Kabul University was killed by the Muslim Freedom Fighters on the 15th of the current month (Shamsi Hijri year (20 May, 1987).

Radio Tehran: Two helicopters of Kabul regime on a mission to bombard resistance positions were shot down by Afghan Mujahideen in Kabul province (13 May, 1987).

It is estimated that 15,000 Muslim Afghan (Government) troops deserted their stations of duty during the last 6 months (News-Urdu: 17 May, 1987).

During other operations in Kabul province, the Muslim Revolutionaries destroyed 2 tanks and killed 7 soldiers of the Communist Troops (17 May, 1987).

The Muslim Revolutionaries in some other operations in Kabul, Baghlan, Bamiyan and Parwan provinces shot down at least 5 helicopters and destroyed 18 tanks and military vehicles of the Communist Troops (21 May, 1987).

Radio Dubai: The official Kabul Radio has reported that 13 'electricity workers' have been killed during an attack by the Mujahideen guerillas east of Kabul. The report said that the workers were returning to their homes after receiving two-week wages when their bus was attacked. The radio called the attack another crime committed by Counter-Revolutionaries, a phrase used by the Soviet-backed government in Afghanistan to describe the Western-backed Mujahideen (News-English: 17 May, 1987).

$B B C$ : Western diplomats in Islamabad say that anti-communist guerillas this month shot down 3 helicopters near the Afghan capital Kabul. According to these diplomats, one helicopter was shot down on Friday as a result of firing from the ground. Two other helicopters were shot down earlier this month in two different incidents (19 May, 1987).

$V O A$ : Western diplomats in Islamabad report that fierce fighting 
had taken place during the last few days in the outskirts of Kabul....

It is said that a bomb exploded in an area where Soviet citizens and officials of the Afghan government and the Communist Party are residing. ... Report has also been received about a car bomb explosion in the Main Market of Kabul on Wednesday. Diplomats say that a bomb also exploded on Tuesday in a car carrying Russian military staff and their family members. Al-Passin says it is being feared that the bomb may have been exploded by disgruntled members of the Communist Party. Diplomats have during the last few weeks been reporting growing tensions in the Party. It is reported that the supporters of the former Afghan Communist leader are demanding more powers. Besides that, a report was received this week about the arrest of Babrak Karmal. Radio Kabul announced on Tuesday that Babrak Karmal had proceeded to Moscow for treatment, while diplomats say that the active supporters of Babrak Karmal were of the view that he has been exiled from the country.

Diplomats reported on Wednesday that battle took place in the north of Kabul during which rocket launchers and heavy arms were used. It is reported that the Mujahideen are attacking Soviet military positions in the outskirts of Kabul. Reports of firing of heavy guns near Kabul airport have also been received. Some news agencies have reported that Soviet citizens and members of Soviet Embassy in Kabul have been asked not go to public places and keep themselves confined to their residences and offices. Latest activities of Mujahideen have been described as the reason for this (Radio Report-Urdu: 9 May, 1987).

Radio Kabul: Security personnel foiled another attempt of the extremists and ground-to-ground missiles and other deadly weapons were seized from a jeep in Shakardara district of Kabul (News-Urdu: 17 May, 1987).

The Central Council of the Trade Unions of the Democratic Republic of Afghanistan has protested to the International Federation of Trade Unions of Construction Workers over the hostile activities of Extremists opposed to National Reconciliation resulting in the death of 13 labourers of the Ministry of Electric Power. The extremists who committed criminal acts a number of times during the nine years of Saur Revolution, have committed another crime. They attacked the vehicle of labourers who were engaged in laying electricity lines and were going back after performing their duty, with rockets and other arms on 15th of May. As a result of this 13 labourers were killed. The messages demanded that the Labour Unions and workers all over the world should condemn the inhuman act of American imperialismbacked extremists. The Afghan Red Crescent Society in a protest note 
has also condemned the barbaric act of extremists (CommentaryUrdu: 18 May, 1987).

\section{Parwan}

Mujahideen sources: 24 April: Mujahideen attack a Soviet-Kabul mobile force near Charikar, provincial headquarters of Parwan, killing four Soviet troops on patrol duty.

26 and 27 April: In a night attack Mujahideen kill 3 troopers and injure several others near Charikar.

On the night of 27th April, the so-called "Saur Revolution" anniversary, the Mujahideen conducted raids inside the provincial capital of Charikar. At least 10 "communists" were killed. Two mediumrange missiles hit the Governor's House.

The Soviet-Kabul authorities retaliated by bombarding Mujahideen bases near Charikar for several days. Thirty-two civilians and 6 Mujahideen were killed in these raids.

Mujahideen attacked a security post in the Salang Highway on April 29.

On 5 May, the 'supporters of Mujahideen' in Gulbahar, situated at. the mouth of the Panjshir valley, planted a time-bomb in a Soviet supply convoy which was carrying ammunition to Panjshir. Two tanks and 4 trucks were destroyed.

The same day (May 5) Mujahideen fired missiles on a Soviet army camp in Qila Surkh area. They also wiped out a security post at Guzar Payan.

Five KHAD 'agents' were killed by Mujahideen in Charikar city on May 10.

A MiG-21 was hit and destroyed by missile attack on May 11 while it was bombing Mujahideen strongholds overlooking the Salang Highway.

They also eliminated a security post near Charikar on May 12 .

The Soviet-Kabul ground-cum-air attacks beginning May 11 on Mujahideen strongholds along the Salang Highway were continuing on May 17. Meanwhile, they had lost a tank alongwith 3 other vehicles and a jet fighter.

Radio Tehran: Afghan Muslim Revolutionaries shot down a MiG21 aircraft of the Kabul regime in Charikar city on May 11. In another operation the Mujahideen killed 7 spies and agents of the Kabul Government and Party in Parwan (News-Urdu: 25 May, 1987).

Radio Kabul: A ten-member armed group gave up their armed activities and joined the process of National Reconciliation in Parwan province (4 May, 1987). 


\section{Kapisa}

Mujahideen sources: On 24 April, Mujahideen attacked a security post in Najrab. Five Government troops and one Mujahid were killed in the fighting.

On 8 May, Mujahideen attacked a group of Soviet soldiers swimming in the river Zamankor, $10 \mathrm{~km}$ inside the main Panjshir Valley, killing 14 of them.

\section{Laghman}

Mujahideen sources: Mujahideen attacked Doab, a sub-divisional centre on May 12. Eight "office bearers" of the Ruling Party were killed. They repeated attack on Doab district on May 17. During this raid forty collaborators of the Russians were captured and 25 killed. Forty klashnikovs, 3 machine guns, one Grinov, one anti-tank and a RPG-7 set were seized by the Mujahideen, among other things.

\section{Logar}

Mujahideen sources: Mujahideen (of various groups) in 'joint' operations fired ground-to-ground missiles on Soviet-Kabul positions in Kolangar and Baraki Barak areas. Heavy losses were inflicted on the enemy.

A large Soviet-Kabul force was sent out to Logar on the following day, 10 May, to deal with Mujahideen. Mujahideen attacked this force with rockets, knocking out 6 tanks, 4 APCs and 3 other vehicles. SovietKabul side was estimated to have lost 60 soldiers and the Mujahideen 20 dead and 15 injured.

Radio Tehran: The Afghan Muslim Revolutionaries in an operation in Logar province last week, destroyed 6 tanks and armoured cars of the Soviet occupation Army. They also killed 29 Soviet-Kabul troops and captured a Soviet officer (News-Urdu: 13 May, 1987).

\section{Wardak}

Nil report from all sources.

\section{4-PSYCHOLOGICAL WARFARE THEMES}

\section{Radio Kabul}

Given below are the major Kabul Radio themes in May 1987 in descending order of recurrence:-

1. Allegations against Pakistan government.

2. Projecting the plan of peace and reconciliation punctuated with call for general amnesty and appealing refugees to return. 
3. Alleged foreign intervention in Afghanistan by U.S. Western media, Pakistan, China and Iran in particular.

4. Inciting Pakistani tribals against the government/armed forces of Pakistan and Afghan refugees.

5. Attacks on the personality of the President of Pakistan.

\section{Radio Moscow}

Given below are the major Moscow media themes in May 1987 in descending order of recurrence:-

1. Criticising Pakistan (on acquisition of arms) from Indo-Soviet perspective, with reference to recent aid packages.

2. Highlighting the Kabul plan for peace and national reconciliation.

3. Alleged foreign intervention in and undeclared war against Afghanistan.

4. Projecting refugees' return and how it is being obstructed by Pakistan and Iran.

5. Lamenting terrorist activities undertaken by counter-revolutionary elements in Afghanistan. 


\section{APPENDIX - 1 \\ ESTIMATE OF LOSSES IN MAY 1987 \\ (MUJAHIDEEN SOURCES)}

\section{Human Losses}

Soviet Casualties

: 280 killed and 132 wounded

Kabul Casualties

: 407 killed and 75 wounded

Soviet-Kabul Casualties

: 903 killed and 358 wounded

Defections

: $1376 \mathrm{Kabul}$ troops defected and

178 captured

Mujahideen Casualties $\quad: 196$ killed and 260 wounded

Afghan Civilian Casualties $\quad$ : 216 killed and 1296 wounded

Material Losses

Soviet-Kabul Material Losses:-

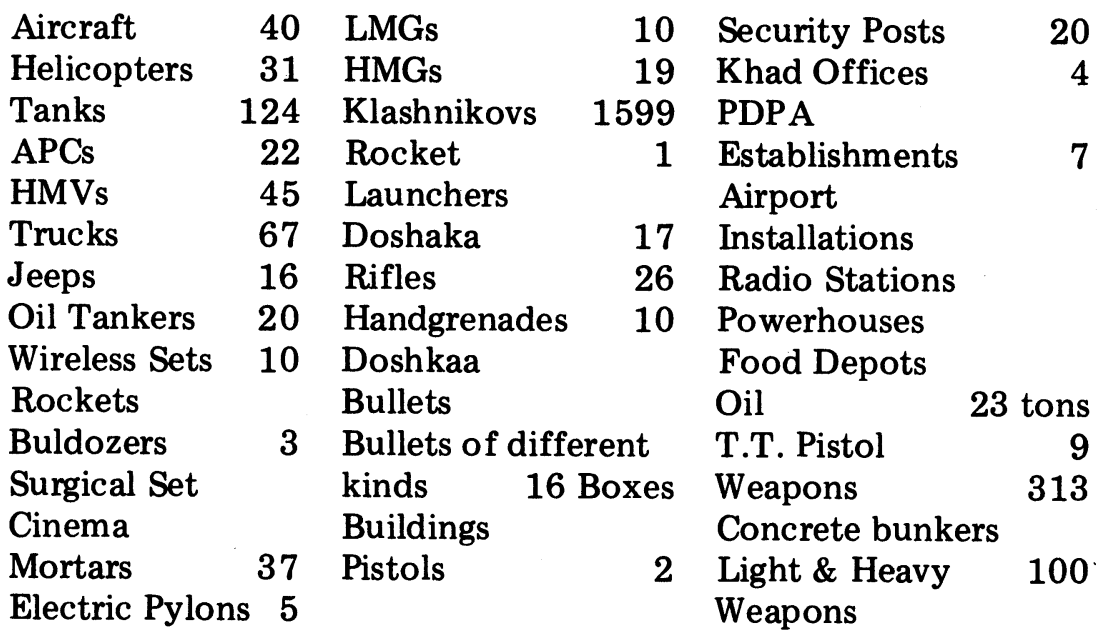

Mujahideen and Afghan Civilian Material Losses:-

Houses $161 \quad$ Based/Hideouts

Crops and Fruit Gardens in Takhar, Kunduz, Faryab

Livestocks $\quad 67 \quad$ Horses and 7 oxen

Arms \& ammunition 2 Anti-aircraft guns

Hospital

1

15 villages in Samangan, 2 in Badghis 


\section{APPENDIX́ -2 \\ ESTIMATE OF LOSSES IN MAY 1987: \\ SOVIET-KABUL (RADIO KABUL) SOURCES} Losses:

Mujahideen and Afghan Civilian ("Counter-Revolutionaries")

Killed

Captured

Returnees
20

5

: 18,137 (Those availing amnesty, voluntarily surrendering, changing allegiance and joining Soviet-Kabul ranks).

Mujahideen Material Losses:

LMGs

Based/Hideouts

Mortars

Missiles

Boxes of Bullets

Quantities of Arms and Ammunitions

Explosives

$$
\begin{array}{rrr}
: & 288 \\
: & 14 \\
: & 9 \\
: & 1100 \\
: & 270 \\
: & 10 & \\
: & 600 & \text { Kgs }
\end{array}
$$

Prisoners released under present amnesty decree: 
APPENDIX - 3

PROVINCEWISE ENGAGEMENTS IN MAY 1987 (MUJAHIDEEN SOURCES)

\begin{tabular}{|c|c|c|c|c|}
\hline \multirow[b]{2}{*}{ Provinces } & \multirow{2}{*}{$\begin{array}{c}\text { Total } \\
\text { Engage- } \\
\text { ments }\end{array}$} & \multirow[b]{2}{*}{$\begin{array}{l}\text { Provincial } \\
\text { Capital }\end{array}$} & \multicolumn{2}{|c|}{ Engagements } \\
\hline & & & $\begin{array}{c}\text { Inside } \\
\text { City }\end{array}$ & $\begin{array}{c}\text { Vicinity of } \\
\text { City }\end{array}$ \\
\hline \multicolumn{5}{|c|}{ Bordering Pakistan } \\
\hline Nimruz & 1 & Zaranj & - & - \\
\hline Hilmand & 19 & Lashkargarh & - & - \\
\hline Qandahar & 56 & Qandahar & 13 & 4 \\
\hline Zabul & 6 & Kalat Gilzai & 3 & 1 \\
\hline Ghazni & 7 & Ghazni & 2 & 1 \\
\hline Paktika & 12 & Sharna & 3 & 1 \\
\hline Paktiya & 30 & Gardez & - & - \\
\hline Ningarhar & 19 & Jalalabad & 1 & - \\
\hline Kunar & 33 & Chagha Sarai & 8 & 6 \\
\hline \multicolumn{5}{|c|}{ Bordering USSR } \\
\hline Badakhshan & 5 & Faizabad & 1 & 1 \\
\hline Takhar & 16 & Taloqan & 1 & - \\
\hline Kunduz & 7 & Kunduz & - & - \\
\hline Baghlan & 21 & Baghlan & 6 & 9 \\
\hline Samangan & 10 & Samangan & 4 & - \\
\hline Balkh & 36 & Mazar Sharif & 3 & 5 \\
\hline Jozjan & 5 & Shebergan & - & 1 \\
\hline Faryab & 7 & Maimana & - & - \\
\hline Badghis & 4 & Qala Nau & - & - \\
\hline \multicolumn{5}{|l|}{ Bordering Iran } \\
\hline Herat & 6 & Herat & 2 & 4 \\
\hline Farah & 3 & Farah & - & 1 \\
\hline (Nimruz) & & (Zaranj) & - & - \\
\hline \multicolumn{5}{|c|}{ Central Provinces } \\
\hline Bamiyan & 1 & Bamiyan & 1 & - \\
\hline Ghor & $1 \overline{4}$ & Chagcharan & - & - \\
\hline Uruzgan & 15 & Tarin Kot & 1 & - \\
\hline \multicolumn{5}{|c|}{ Kabul \& Adjacent Provinces } \\
\hline Kabul & 45 & Kabul & 5 & 7 \\
\hline Parwan & 41 & Charikar & 5 & 5 \\
\hline Kapisa & 2 & Mahmud-i-Raqi & & \\
\hline Laghman & 3 & Mehtarlam & & \\
\hline Logar & 8 & Pule Alam & 6 & 1 \\
\hline Wardak & - & Koteasro & & \\
\hline TOTAL: & 431 & & 59 & 49 \\
\hline
\end{tabular}




$$
\text { APPENDIX - } 4
$$

MUJAHIDEEN MOBILE \& IMMOBILE TARGETS AND SOVIET-KABUL OPERATIONS IN MAY 1987

(MUJAHIDEEN SOURCES)

\begin{tabular}{|c|c|c|c|c|}
\hline \multirow{2}{*}{ Provinces } & \multicolumn{2}{|c|}{ Mujahideen Targets } & \multicolumn{2}{|c|}{$\begin{array}{c}\text { Soviet-Kabul } \\
\text { Operations }\end{array}$} \\
\hline & Mobile & Immobile & Air & Ground \\
\hline \multicolumn{5}{|c|}{ Bordering Pakistan } \\
\hline Nimruz & - & 1 & - & - \\
\hline Hilmand & 3 & 12 & - & 4 \\
\hline Qandahar & 26 & 23 & 2 & 3 \\
\hline Zabul & 4 & 2 & - & - \\
\hline Ghazni & 4 & 2 & 1 & - \\
\hline Paktika & 2 & 10 & - & - \\
\hline Paktiya & 13 & 9 & 4 & 4 \\
\hline Ningarhar & 8 & 9 & 1 & 1 \\
\hline Kunar & 10 & 23 & - & - \\
\hline \multicolumn{5}{|c|}{ Bordering USSR } \\
\hline Badakhshan & 2 & 1 & 2 & - \\
\hline Takhar & 5 & 3 & 4 & 4 \\
\hline Kunduz & 3 & 2 & - & 2 \\
\hline Baghlan & 12 & 9 & - & - \\
\hline Samangan & 3 & 5 & 1 & 1 \\
\hline Balkh & 17 & 7 & 5 & 7 \\
\hline Jozjan & 1 & 1 & - & 3 \\
\hline Faryab & - & 5 & - & 2 \\
\hline Badghis & 2 & - & 1 & 1 \\
\hline \multicolumn{5}{|l|}{ Bordering Iran } \\
\hline Herat & 2 & 2 & - & 2 \\
\hline Farah & 3 & - & - & - \\
\hline (Nimruz) & - & - & - & - \\
\hline \multicolumn{5}{|c|}{ Central Afghanistan } \\
\hline Bamiyan & 1 & - & - & - \\
\hline Ghor & 5 & 7 & - & 2 \\
\hline Uruzgan & 6 & 3 & - & 6 \\
\hline \multicolumn{5}{|c|}{ Kabul \& Adjacent Provinces } \\
\hline Kabul & 25 & 10 & 5 & 6 \\
\hline Parwan & 15 & 9 & 4 & 13 \\
\hline Kapisa & 1 & 1 & - & - \\
\hline Laghman & - & 3 & - & - \\
\hline Logar & - & 3 & 4 & 1 \\
\hline Wardak & - & - & - & - \\
\hline TOTAL: & 173 & 162 & 34 & 62 \\
\hline
\end{tabular}




\section{APPENDIX - 5}

PROVINCEWISE SOVIET-KABUL SECURITY OPERATIONS AND RETURNEES IN MAY 1987 (Radio Kabul)

\begin{tabular}{|c|c|c|c|c|}
\hline \multirow[b]{2}{*}{ Provinces } & \multirow{2}{*}{$\begin{array}{c}\text { Soviet- } \\
\text { Kabul } \\
\text { Operations }\end{array}$} & \multirow{2}{*}{$\begin{array}{c}\text { Counter- } \\
\text { Revolu- } \\
\text { tionaries } \\
\text { Action } \\
\end{array}$} & \multicolumn{2}{|c|}{$R$ e $t u r n$ e e $s$} \\
\hline & & & $\begin{array}{c}\text { Total } \\
\text { Reports }\end{array}$ & Numbers \\
\hline \multicolumn{5}{|c|}{ Bordering Pakistan } \\
\hline Nimruz & - & - & 2 & 225 \\
\hline Hilmand & - & - & - & 42 \\
\hline Qandahar & 1 & 2 & - & 125 \\
\hline Zabul & $=$ & - & - & - \\
\hline Ghazni & - & - & - & - \\
\hline Paktika & - & - & - & - \\
\hline Paktiya & - & - & 1 & 6500 \\
\hline Ningarhar & - & - & 10 & 928 \\
\hline Kunar & - & - & 3 & 1790 \\
\hline \multicolumn{5}{|c|}{ Bordering USSR } \\
\hline Badakhshal & - & - & - & - \\
\hline Takhar & - & - & 5 & 385 \\
\hline Kunduz & - & - & 1 & 54 \\
\hline Baghlan & 2 & - & 2 & 130 \\
\hline Samangan & - & - & - & - \\
\hline Balkh & - & - & 2 & 320 \\
\hline Jozjan & - & - & 2 & 193 \\
\hline Faryab & - & 3 & 9 & 779 \\
\hline Badghis & 1 & 1 & 2 & 125 \\
\hline \multicolumn{5}{|l|}{ Bordering Iran } \\
\hline Herat & - & - & 7 & 4821 \\
\hline Farah & - & 1 & 5 & 1009 \\
\hline (Nimruz) & - & - & - & - \\
\hline \multicolumn{5}{|c|}{ Central Provinces } \\
\hline Bamiyan & - & - & - & - \\
\hline Ghor & - & - & - & - \\
\hline Uruzgan & - & - & - & - \\
\hline \multicolumn{5}{|c|}{ Kabul \& Adjacent Provinces } \\
\hline Kabul & 3 & 2 & 3 & 482 \\
\hline Parwan & - & - & 1 & 10 \\
\hline Kapisa & - & - & - & - \\
\hline Laghman & - & - & - & - \\
\hline Logar & 1 & - & - & - \\
\hline Wardak & 二 & 一 & 2 & 220 \\
\hline TOTAL: & 10 & 10 & 57 & $1,81,138$ \\
\hline
\end{tabular}




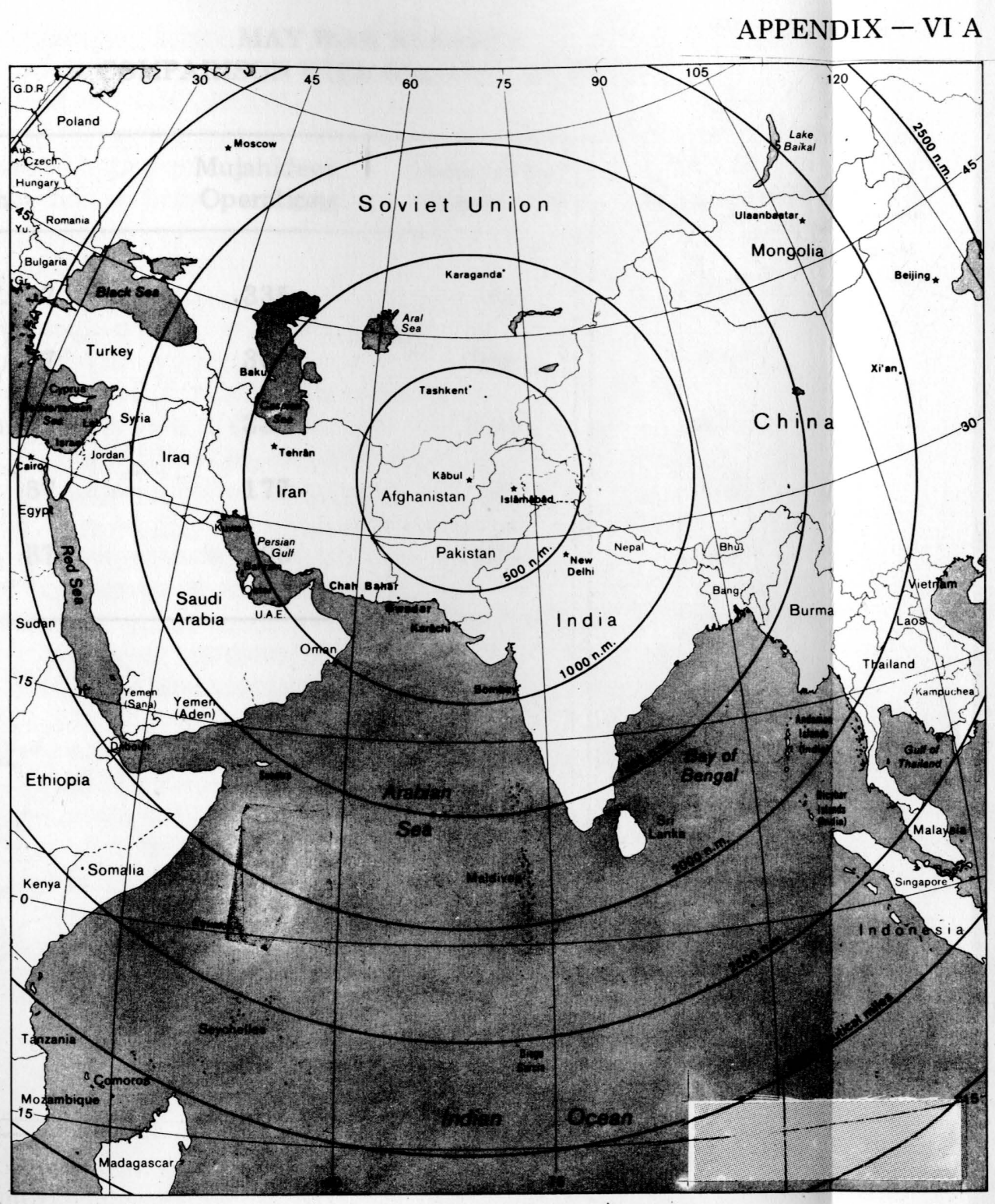

Map of Afghanistan

APPENDIX - VI B

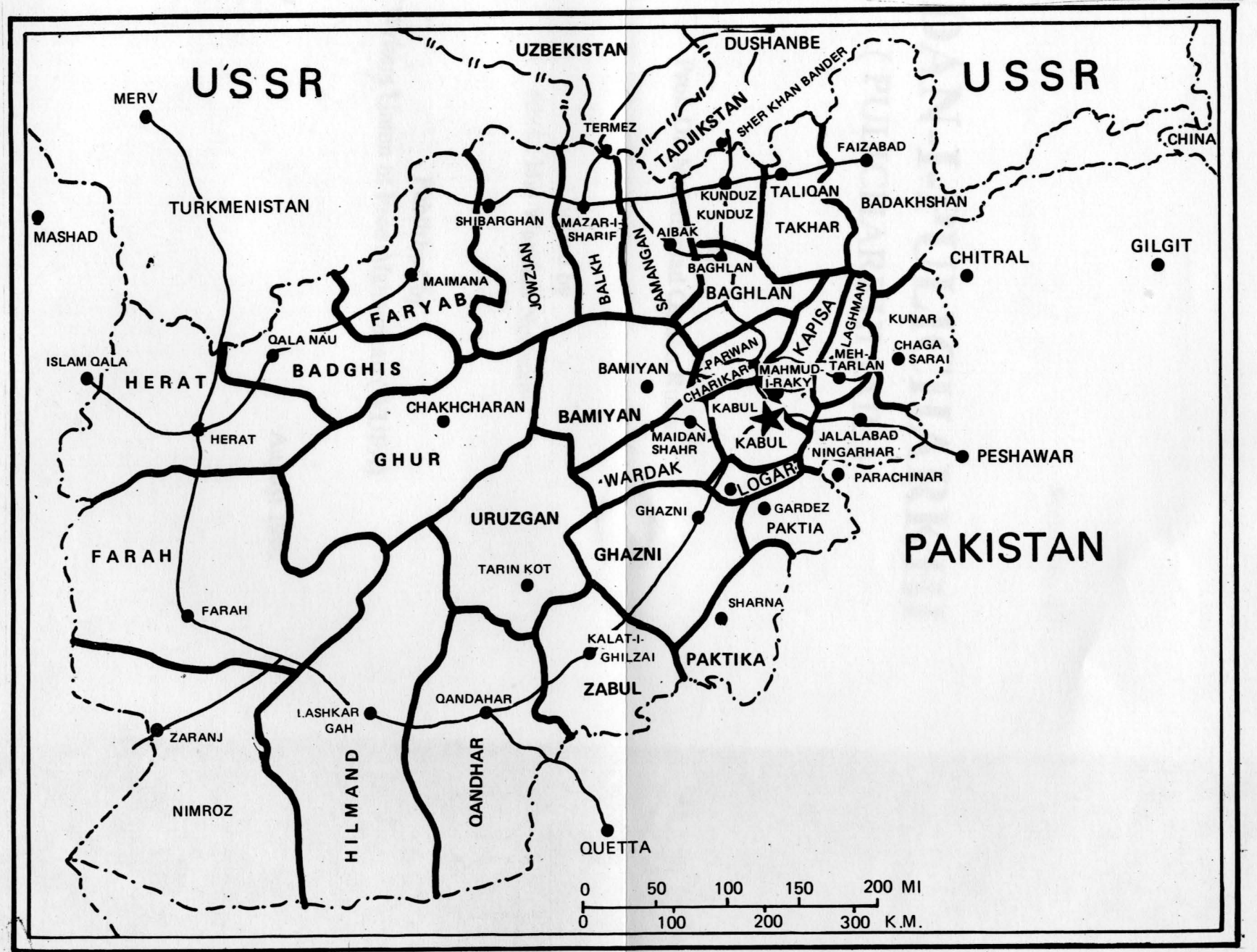

Mujahideen sources: Conflict reported during May 1987 in 28 provinces. Province from where no war report received: Wardak

Radio Kabul: Conflict reported during May 1987 in 8 provinces. These Provinces are: Qandahar, Zabul, Baghlan, Faryab, Badghis, Farah, Kabul and Logar. 


\section{APPENDIX -7 \\ MAY WAR REPORTS \\ COMPARISON WITH PREVIOUS MONTHS}

\begin{tabular}{lcccc}
\hline Month & $\begin{array}{c}\text { Mujahideen } \\
\text { Operations }\end{array}$ & $\begin{array}{c}\text { Soviet-Kabul } \\
\text { Operations }\end{array}$ & $\begin{array}{c}\text { Total } \\
\text { Engagements }\end{array}$ \\
\hline May & 87 & 335 & 96 & 431 \\
April & 87 & 300 & 198 & 498 \\
March & 87 & 339 & 149 & 488 \\
Feb. 87 & 177 & 35 & 212 \\
Jan. & 87 & 309 & 133 & 422 \\
\hline
\end{tabular}




\section{NOTES}

The monthly Afghanistan Report is a carefully researched document for the benefit of scholars and policy-makers. Its aim is to present an objective analysis of the Afghan resistance, and the Soviet-Kabul military and psychological warfare.

The information and overt intelligence incorporated in this report after collection, and evaluation is based on primary and secondary sources of all parties in the conflict. The primary sources availed are the monitoring reports of Pakistan Broadcasting Corporation covering Moscow, Tashkent, Dushambe and Kabul broadcasts, Soviet Embassy handouts, and information received from the Afghan Documentation Centre, The Afghan Islamic Press and the Agency Afghan Press files. Secondary sources are the international media, and research papers and writings of the academicians. We are conscious of the paucity of correct, complete and timely information from closed societies, as also the lack of formal and trained command, control, communication and intelligence set-up among the Mujahideen.

Figures of casualties and material losses given in Section 3 are in only those few cases where such inclusions were necessary for proper appreciation of the given events.

Losses reported in "Soviet-Kabul" category are often physically not verifiable by the Mujahideen and therefore mostly speculative.

The reports received and reported are subject to the process of verification, whenever possible, which may include interviewing with those most directly informed on the events.

Dates given in parenthesis in section 3 are of the actual broadcast.

Voice of Islamic Revolutionary Afghanistan (VOIR).

\section{PERIOD COVERED}

Facts and figures given in this study are based on reports mostly received during May $1-31,1987$. 


\title{
II.- THE POLITICO-ECONOMIC AND CULTURAL DEVELOPMENTS IN AFGHANISTAN
}

\author{
1 - FOREIGN VISITS AND AGREEMENTS
}

\section{Messages}

Messages on various occasions were sent to, received from and exchanged with the following countries and organizations: German Democratic Republic, Hungary, Iraq, Kampuchea, Laos, People's Democratic Republic of Korea, Palestine Liberation Organization and USSR.

\section{East Europe}

Abdul Wakil, member PDPA CC Politburo and DRA Minister of Foreign Affairs, heading a delegation visited Czechoslovakia, Poland and Bulgaria from May 18 to 20,20 to 22 and 22 to 25,1987 respectively and held talks with the state and party leaders of these countries on mutual relations between the states and parties and bilateral discussions. Wakil spoke about the DRA national reconciliation programme, formation of national unity government to the extent of coalition with opposition and the DRA stand about Pak-Afghan Geneva talks.

During his visit, Wakil also signed the following documents:-

a. In Czechoslovakia. Memorandum of understanding or adoption of a review of decisions and measures for further broadening and expansion of relations and cooperation in political, economic, scientific, cultural and technical fields between Afghanistan and Czechoslovakia.

b. In Poland

(i) Protocol on cooperation for 1987-90 between the Foreign Ministries of Afghanistan and Poland.

(ii) Agreement on cultural and scientific cooperation for 1987-89 between Afghanistan and Poland.

c. In Bulgaria

(i) Protocol on cooperation for 1987-89 between the Foreign Ministries of Afghanistan and Bulgaria.

(ii) Agreement on cultural and scientific cooperation for 1987-89 between Afghanistan and Bulgaria.

Abdul Wakil returned Kabul on May 28, 1987. On his way back, he stayed in Moscow on May 26-28, 1987 and met with his Soviet 
counterpart Mr. Edward Shavardnadze, giving him necessary explanation on the implementation of national reconciliation process, relations with other countries, increasing international support to the DRA in the light of its national reconciliation policy and their efforts for the settlement of the issues around Afghanistan. In return Mr. Shaverdnadze emphasised that the Soviet Union, in future too, would continue to render all round assistance and cooperation to the DRA for cessation of bloodshed and for social and economic development (Radio Kabul, 22, 23, 24 May, $B B C, 24$ May, Radio Moscow, 23 May and $K N T, 20$, $23,24,25,31$ May).

Arab

The office of the Arab Libyan Popular Socialist Jamahiriya in Kabul donated on May 5, fifteen titles of textbooks and religious books including Holy Quran, Quran interpretation, Quran recitation on record and literary books numbering 700 volumes to the Afghan Centre for Islamic Studies (KNT, 6 May).

\section{Bulgaria}

Abdul Rahim Hatif, Chairman of the DRA National Front, heading a delegation, visited Sofia in the month of May to participate in the 10th congress of the Bulgarian Fatherland Front (KNT, 12 May).

\section{France}

The DRA Ministry of Foreign Affairs lodged a protest with the Embassy of France in Kabul on May 11, 1987 condemning the French Minister for Foreign Affairs meeting with the Afghan refugees leader in Pakistan, giving an assurance for French support and increase in assistance to them and conclusion of an agreement with the Pakistan authorities to this effect during his visit to Pakistan on May 7-8, 1987. The Ministry termed it as interventionist assertions and actions of the French Minister and called on French Government for refraining from such activities in future (Radio Kabul, 11 May and KNT, 12 May).

\section{Greece}

Mir Saheb Karwal, alternate member of the Politburo and Secretary of the DRA CC heading a Party delegation visited Athens in the month of May to participate in the 12th congress of the Communist Party of Greece (KNT, 11 May).

\section{Hungary}

Feda Mohammad Dehnashin, First Vice Chairman of the DRA 
National Front visited Hungary from May 11 to 20, 1987 on a goodwill visit (KNT, 12 May).

India

Mr. N.D. Tiwari, Minister for External Affairs of India heading a delegation visited Kabul from May 3 to 5, 1987 to participate in the 8th session of Indo-Afghan Joint Commission on Technical, Trade and Economic cooperation. The Afghan delegation to the session was led by his counterpart Abdul Wakil. Mr. Tiwari also laid the foundation stone of an expansion project of the Indira Gandhi Institute of Child Health, Kabul, which is run under the Technical cooperation of India. The expansion projects, costing 330 million Afghanis from Indian gratis aid, will include 100-bed surgery ward, operation room, laboratory, X-Ray, Physiotherapy and a conference hall.

The two delegations also held talks on various regional and international issues and agreed on adoption of necessary measures for further expansion and consolidation of relations and mutually beneficial cooperation between the DRA and India.

During the visit, Mr. Tiwari met with Dr. Najib, Keshtmand, Haji Mohammad Samkani and also participated in a meeting of AfghanIndian Friendship Society. He visited the Kabul Industrial Port, being built with Indian assistance, Sikh Gurdwara at Karta Parwan and Hindu Dharamsal at Asmai, Kabul.

On May 5, 1987 before his departure, Mr. Tiwari addressed a press conference at the Afghan Ministry of Foreign Affairs, in which he expressed his country's support to the DRA national reconciliation policy and wished for peaceful solution of the issues around Afghanistan. He also blamed Pakistan for involvement in the Punjab affairs. Expressing apprehensions about the so-called Pakistan's nuclear programme and quest for sophisticated weapons i.e. AWACS etc., Mr. Tiwari said:

"We do not believe that Pakistan intends to use these weapons against any imaginary threat from Afghanistan. We are convinced that these weapons are being stored for use against India. This has been proved in the past".

(All India Radio, 3, 4 May, Radio Bangladesh, 3 May, APP, 2 May, BBC, 3 May, Radio Moscow, 4, 6 May, Radio Kabul, 3, 4, 5 May and $K N T$, 4, 5 May).

Sher Jan Mazdooryar, Minister for Transport of the DRA, during his visit to India, met Mr. Priya Ranjan Das, the Indian Minister of State for Trade and discussed matters in connection with the further strengthening of bilateral trade and economic relations. Increase in trade turn 
over between the two countries was examined which totals today 375 million rupees. The Indian side expressed preparedness to broaden the export to Afghanistan of medicinal new material, pharmaceutics, mechanical engineering products, transport facilities, auto-tyres and a number of staple export items ( $A I R, 27,29$ May).

\section{Mongolia}

Ever-first Barter Trade Protocol valid for 1987-88 between Afghanistan and Mongolia was signed in Kabul on May 24, 1987 by the Deputy Ministers of Trade of the two countries on behalf of their respective governments. According to the protocol, dry fruits, handicrafts etc goods worth US $\$ 3.2$ million will be exported from Afghanistan to Mongolia during the year in exchange for exporting foodstuff etc from that country.

Similarly a contract for import and export of commercial goods between the Fruit Export Enterprise of the DRA and Ministry of External Trade of Mongolia was also signed in Kabul on the same day (KNT, 25 May).

A protocol on cooperation between the Writer's Unions of DRA and Mongolia for the years 1987-90 was signed on May 25, 1987 in Kabul (KNT, 26 May).

\section{Pakistan}

Rasul Bakhsh Palejo a political figure of Sindh and leader of Awami National Party of Pakistan arrived Kabul on May 4, 1987. At the airport, he was received by some officials of the International Affairs and Tribes, Nationalities and Border Affairs Departments of PDPA CC and Ajmal Khattak. On May 6, 1987 Mr. Palejo placed floral wreath on the monument of Revolution martyres'. In his interview telecast on Kabul TV on May 10, 1987 Mr. Palejo blamed America for heightening the tense situation in the region, by posing an undeclared war against Afghanistan which had culminated even in creating enormous socio-political problems for Pakistan. He also supported the national reconciliation programme of the DRA government and maintained that it would guarantee not only the interests of Afghan people but those of the people of Pakistan too (Radio Kabul, 4, 6, May).

The Charge d'. Affairs of the Embassy of the Islamic Republic of Pakistan in Kabul was handed over a protest note saying:

"On April 29, 1987 two F-16 planes of the Pakistan Air Force entered the air-space of Afghanistan in Paktia province. This act of the Pakistan Air Force is considered a clear violation of the Afghan air-space and is against all the recognised international laws 
and norms of inter-state relations. The Air Defence Force of Afghanistan was compelled to react and as a result one of the plane overflying the Khost Loi Woleswali was shot down.

Inspite of the repeated protests of the Afghan government, air violation of Afghanistan by that country is continuing. It may be pointed out that such provocative activities by the Pakistani authorities will result in creating tension in relations between the two countries, and the dire consequences of which will rest with the Pakistan authorities and they will also be responsible for the political outcome of the provocative activities" (Radio Kabul, 1 May).

\section{Poland}

Manfred Gorywoda, Deputy Chairman of the Council of Ministers of Poland, heading a delegation visited Kabul from May 24 to 31, 1987 and signed a protocol on economic and technical cooperation between Afghanistan and Poland. On behalf of the DRA, the protocol was signed by Mohammad Aziz, Deputy Chairman of the DRA Council of Ministers and President of the DRA Committee of Planning Affairs. Similarly a protocol on cooperation between the Ministries of Commerce of the two countries was also signed in his presence (Radio Kabul, 29 May. and $K N T, 26$ May).

\section{Romania}

The ever first session of the Afghan-Romanian Commission on cooperation was held in Kabul from May 6 to 10, 1987. Mohammad Khan Jalalar, DRA Minister of Commerce headed his country delegation to the session while that of Romania was led by Gorgy Gazan, Minister of State for Foreign Trade of that country. At the end of the session, a memorandum of understanding was signed. Acçording to it main direction for technical and economic cooperation in some projects of light industries, mines, agriculture and construction in Afghanistan were earmarked. It was also decided that experts of both the countries would visit each others country for further consultation and carrying out technical and economic studies in this regard. Separate protocols will be signed for each project by concerned authorities of the two countries.

A commercial protocol was also signed in the session, which provides for expansion of trade between the two countries and Romanian assistance to state and private sectors of Afghanistan and formation of Joint Trading Companies (KNT, 6, 9, 11 May). 


\section{Syria}

Najmuddin Kawyani, Secretary of the Central Committee of the PDPA, led a delegation to the International Symposium on the 70th anniversary of October revolution under "Lenin and East" held in Syria, returned home on May 6. During his stay in Damascus, Kawyani met with the authorities of the Arab Socialist Baath Party of Syria. He also signed a protocol on cooperation between the parties (KNT, 6 May).

\section{USA}

An arranged march/meeting of the Kabul citizens, also including Ulema, Clergymen, local and Foreign Qaries participants of the International Contest recitation of Holy Quran, was held on May 25, 1987 in the Peace Avenue and Arian Square, Kabul, denouncing the alleged attack on the shrine of Holy Kherqa of Prophet Mohammad (PBUH) and killing of Maulvi Mohammad Nabi, the Imam of Holy Kherqa mosque on May 17. The meeting was addressed amongst others, by Maulvi Abdul Jamil Zarifi, DRA Minister of Islamic Affairs and Trusts. The demonstrators chanted slogans against the extremists counterrevolution' and their supporters, USA Imperialism and regional reaction. They also marched in front of the USA Embassy and threw several protest letters in the Embassy premises. The main banner of the demonstrators carried the inscription as "the hostile attack on the sacred shrine of Prophet's costume is the biggest crime against muslims", (KNT, 26 May).

\section{USSR}

Bareq Shafeie, Editor-in-Chief of the daily Haqiqat-e-Enqilab-eSaur, Kabul, organ of the PDPA CC heading a delegation visited Moscow in the month of May 1987 to participate in the 75th anniversary of the establishment of daily Pravada, organ of the CPSU CC (KNT, 2 May).

G.T. Vlademorovna, Vice-Chairman of the Soviet State Committee for Technical and Professional Education visited $\mathrm{Kabul}$ in the second week of May 1987 and signed a protocol on cooperation in technical and professional education. Burhan Ghiasi, DRA Minister of Higher and Professional Education signed the protocol on behalf of his government. Under the protocol, the Soviet side will give a gratis aid of two million and five million Roubles respectively for the already established professional and technical schools and setting up of four new such schools in Afghanistan (KNT, 7, 11 May and Radio Kabul, 10 May).

Mohammad Sharif, Chief of North Zone, heading a Party and 
State delegation of Balkh, Jauzjan, Samangan and Baghlan Provinces visited Surkhan Darya, Samarkand, Tashkent and Farghana Provinces of Uzbekistan Soviet Republic from May 8 to 14, 1987. The delegation held talks with concerned authorities there on exchange of experiences and bilateral economic, cultural and technical cooperation and signed a protocol for delivery of goods worth six million Roubles including training material for schools, communication instruments, electrical equipment, consumer goods, agricultural and construction machinery by the Soviet side for the above said four Afghanistan provinces (KNT, 9, 16 May).

Chief of Academy of Diplomacy, Soviet Ministry of Foreign Affairs, heading a delegation visited Kabul in the month of May 1987 to evaluate the spheres of assistance of his academy with the Institute of Diplomacy, DRA Ministry of Foreign Affairs (KNT, 12 May).

Mirza Ali Ibrahimovich, Chairman of the Uzbek Soviet Republic State Committee for Sports and Physical Training, heading a delegation visited Kabul in the month of May 1987 and gave sports goods to the DRA State Committee for Sports and Physical Training as assisted by his organisation (KNT, 13 May).

Boris Ivanyvich Aristov, Soviet Minister for Foreign Trade heading a delegation visited Kabul from May 13 to 18,1987 and signed the following documents:-

a. Inter-Governmental agreement on grant of economic aid by the USSR to the DRA.

b. Memorandum of understanding on activities of the Joint Afghan-Soviet trading companies M/S AFTENO and AFTORG.

c. Protocol on opening of Afghan handicrafts stores in Moscow and other big cities of the Soviet Union.

(BBC, 14, 18 May, Radio Moscow, 18 May, Radio Kabul, 14, 16, 19 May and $K N T, 14,18$ May).

A 20 day Soviet Youth Photo Exhibition called "Youth of the Soviet Union in the DRA" was opened on May 14, 1987 at the Soviet House of Science and Culture, Kabul. Farid Ahmad Mazdak, alternate member of the PDPA CC Politburo and First Secretary of the Democratic Youth Organisation of Afghanistan and Alexander Rybakov, head of the Leninist Komsomol delegation delivered speeches on the occasion, highlighting the struggles and activities of the Soviet Youth, solidarity between Afghan and Soviet Youth in realization of the aspirations of national and democratic revolution, and traditional AfghanSoviet friendship (KNT, 16 May).

A cooperation agreement in the field of Public Health was signed between the two countries, laying down the following:- 
a. The Afghan side will receive medical equipment costing ten million Roubles from the gratis aid of the Soviet Union to the DRA.

b. Cooperation of the health institutions of the Soviet Union with those of the DRA.

c. Training of Afghan Cadres in different fields of Public Health by the Soviet Union.

d. Other cooperations in the sphere of Public Health.

Zimbabwe

Sarwar Yurish, President of the State Committee of Bakhtar Information Agency (BIA) left Kabul for Zimbabwe on May 31, 1987 to participate in the Conference of Information Ministers of the NonAligned Countries to be held in Harare.

\section{2-POLITICAL DEVELOPMENTS}

\section{Periodic Session of PDPA CC Politburo}

Two periodic sessions of the PDPA CC Politburo were held during the month of May 1987 wherein the points as mentioned against each were discussed and decisions taken thereon:-

a. Session on May 7, 1987. This session was held under the single agenda of "the process of national reconciliation, the tasks of further strengthening the cohesion of party ranks". The Politburo also discussed at length the shortfalls in the provincial party committees. It discussed:-

(i) Preliminary results of sessions of the Primary Party Organizations.

(ii) Evaluation of the activities of the Party Committees of Parwan and Takhar Provinces, Herat City and Ghani Khel of Shinwar Division in Ningarhar Province. The meeting expressed dissatisfaction over the performance of the Primary Party Committees of Parwan and Herat provinces and directed the Secretaries of these committees to improve their functioning.

(iii) Report of Najmuddin Kawaiani, Secretary of the PDPA CC on participation of the DRA delegation in the international symposium entitled 'The October Revolution and the People of East' held in Damascus in April 1987.

(iv) Establishment of Press Centre at Kabul in the framework of DRA Journalists' Union.

(v) Publication of a Journal 'Kabul University', as publicity 
organ of the Kabul University and Party Committee of the University.

(Radio Kabul, 7 May and KNT, 9 May).

b. Session on May 31,1987

(i) Results of countrywide work drive launched in 1365 HS (ended on March 31, 1987).

(ii) Report presented by the Commissions of the PDPA CC on the establishment of Unions of Craftsmen and the convocation of their founding Congress.

(iii) Issues pertaining to the elevation of the role of the All Afghanistan Women's Council.

(iv) Activity of work brigades of college and school students in HS 1365.

(v) Report presented by Abdul Wakil, Afghan Foreign Minister on the participation of DRA delegation in the 6th Ministerial session of the countries of Group 77.

(vi) Report of Abdul Wakil on the results of the official and friendly visit to Afghanistan of Mr. Tiwari, the Minister of External Affairs of India.

\section{National Reconciliation Programme}

In the process of implementation of the National Reconciliation Programme, the DRA RC Presidium issued the following decrees during the month of May 1987:-

a. Decree on Exemption of Taxes etc. The decree provides for exemption of payment of property, municipality, electricity, telephone, telex and postal services charges and taxes, interest and penalties on bank's credits by the Afghan repatriates for the period of their refuge abroad. However, the original bank's credits are to be paid in one year's period after return (KNT, 6 May).

b. Decree on Re-Admission to Job and Payment of Pension Rights etc. Under the decree all those prisoners who had been sentenced for committing crime after April Revolution (1978) against the internal and external security of the country and now were either released or term of their imprisonment pardoned under various amnesty decrees, the repatriates and the surrendered armed persons would be re-appointed on their previous jobs/grade/rank and re-given the rights of pension (KNT, 21 May).

c. Decree on Pardoning of Prisoners on occasion of Eid-ul-Fitr. The decree provides the pardoning of all those prisoners whose 
remaining term of imprisonment is one or less then one year. However, the persons imprisoned for committing terroristic and espionage crimes, would not be benefitted from the decree (KNT, 29 May).

\section{Periodic Session of CCRA Held}

Periodic session of the Coordinating Commission for Repatriates Affairs (CCRA) was held on May 25, with the participation of Najib, Sultan Ali Keshtmand and high officials of the party and the government of the DRA. At the outset of the session, Dr. Mohammad Hassan Sharq, President of the department for repatriates affairs spoke on the achievements of the department and the facilities provided for the return of the repatriates to the country. Minister of Finance and Chairman of the Department of Repatriate Affairs of Herat and Ningarhar provinces reported on the accomplished achievements of the related departments and the assistance rendered to repatriates. Najib gave necessary instructions to related organs for further assistance to repatriates (KNT, 26 May).

\section{New Chairman of the DRA Journalists Union}

In an extraordinary Plenum of the Central Council of the DRA Journalists Union, held on May 24, 1987, Mohammad Hassan Bareq Shafae, Editor-in-Chief of the daily Haqiqat-e-Enqilab-e-Saur, organ of the PDPA CC was elected as the Chairman of its Central Council. The post was vacant since the promotion and transfer of Dr. Haider Masoud, the former Chairman as the Secretary of PDPA CC and Head of Education, Extension and Propaganda Department of the PDPA CC last year (KNT, 25 May).

\section{National Reconciliation Committees Set Up in Afghanistan}

Afghanistan has so far set up one hundred and sixty National Reconciliation Committees. More than twenty one thousand members of anti-government groups have laid down arms since the reconciliation policy was announced on the 15th of January.

Afghanistan's Foreign Minister Abdul Wakil has told a news conference in Kabul that the United States, Pakistan, Iran and a number of other countries and also reactionary forces are seeking to frustrate national reconciliation in his country (Radio Moscow, 8 May).

\section{Afghan Government Forcing Youths for Conscription}

Western diplomats have said that the Soviet-installed Afghan government is forcing a large number of Afghan youths to join the 
Afghan army. The diplomats in Islamabad said that the troops are sent to apprehend the youths. They have also reported increasing protest by their parents. The diplomats said that the guards outside Sarandoi recruitment Centre had recently tried to control a big number of demonstrators at gun-point (VOA, 13 May).

\section{POLITICAL SITUATION}

180 Prisoners Released from Pule Charki Jail

As a mark of respect to the Eid-ul-Fitr and in accordance with a decree of the Presidium of the Revolutionary Council 180 prisoners were released from Central Pule Charki Jail on 27 May (Radio Kabul, 27 May).

Split in Afghan Communist Party leads to Several Bombings inside Kabul

Western diplomats say a split in the Afghan Communist Party appears to have led to several bombings inside the Kabul, the Afghan capital. The Islamabad based diplomats say two bombs were exploded on 6 May in a residential section of Kabul where Soviet civilians and Afghan government officials live. There was also reported a car bombing on 6th May in one of the city's main bazars. There is no information of casualties. These diplomats say there is speculation that the bombings may have been the work of splitted Communist Party members who have been pressing for more power in the government ( $V O A, 8$ May).

\section{Karmal Leaves for Soviet Union for Medical Treatment}

On April 14, member of the Central Committee of Peoples Democratic Party, Babrak Karmal on the advice of the physicians left for Soviet Union for medical treatment and rest.

Before his departure, Babrak Karmal met the General Secretary of the Central Committee of the Peoples Democratic Party Comrade Najib and members and Secretaries of the Party.

$\mathrm{He}$ was seen off at the Kabul airport by the Secretaries of the Party's Central Committee, Comrades, Saleh Mohammad Zaire and Noor Ahmed Noor, Mahmood Baryali, the Soviet Ambassador in Kabul and members of the family of Babrak Karmal (Radio Kabul, 4 May).

Karmal Arrested, Jailed

The former President of Kabul regime Babrak Karmal has been arrested and sent to jail.

An informed source told the correspondent of the Islamic Re- 
public News Agency that under the direction of the Revolutionary Council, Babrak Karmal has been arrested by the security forces and sent to Pule Charki jail.

This diplomatic source added that Karmal had been under house arrest for some time past (Radio Tehran, 2 May, Radio Bangladesh, 3 May).

\section{Karmal, Anahita, Baryalai Arrested}

Reports reaching New Delhi said former Afghan leader Babrak Karmal, Anahita Ratibzad and Mahmood Baryali were arrested. Afghan leader Najib made the arrests in a demonstration of power, the reports said.

According to observers, Karmal is still regarded as a serious challenger to Najib because of his relatively large popularity (PPI/ DPA, 5 May).

\section{Counter-Revolutionaries Kill Qandahar City Chairman of} Reconciliation Commission

The Bakhtar News Agency has reported that "counter-revolutionaries" in Afghanistan killed the Chairman of the National Reconciliation Commission in the city of Qandahar, Haji Mohammad Aman on 17 May. At a mass meeting in Qandahar the participants voiced their resolve to frustrate the schemes of the enemies of national reconciliation (Radio Moscow, 11 May).

\section{Kabul University Polytechnic Chief Killed}

Correspondent of the Voice of the Islamic Revolution of Afghanistan has reported that President of the Party Committee of the Polytechnic Institute of Kabul University was killed by the Muslim freedom fighters of fifteenth of May 1987 (VIRA, 20 May).

\section{Workers Killed in Missile Attack by Counter-Revolutionaries}

The "counter-revolutionary" extremists fired missiles on the workers of Spinghar Construction Company, while they were returning to their homes from duty this afternoon. As a result, thirteen workers were martyred (Radio Kabul, 16 May).

\section{Counter-Revolutionaries Kill Imam of Qandahar Mosque}

On the 17th of May 1987 a group of "bandits" made their way into a mosque in one of the districts of city of Qandahar and killed Imam Mohammad Nabi. The religious leader was known for his support for the policy of national reconciliation (Radio Moscow, 22 May). 


\section{3 - NATIONALITIES POLICY}

\section{Holding of Jirgas/Meetings by the Party and State High-Ups}

The process of holding Jirgas and meetings of the pro-regime elders and elements for explaining the National Reconciliation Programme to them and ascertaining their support and cooperation to its implementation was continued during the month of May 1987. The Jirgas/meetings chaired and addressed by Dr. Najib, Haji Mohammad Chamkani and other high-ups of the Party and State are summed up as under:-

a. Jirgas/Meetings Addressed by Dr. Najib

(i) Jirga of elders from Waras, Punjab, Yakaulang, Kahmard and Saighan Palace, Kabul on May 2, 1987 (KNT, 3 May).

(ii) Meeting of Ulema, Clergies and other concerned with the Islamic Affairs at the Islamic Research Centre, Kabul on May 13, 1987 (Radio Kabul, 14 May).

(iii) Jirga of elders of Nejrab district, Kapisa Province at Dilkusha Palace, Kabul on May 20, 1987 (Radio Kabul and $K N T, 21$ May).

(iv) Jirga of elders of Kuchi tribes at the DRA RC Headquarters, Kabul on May 21, 1987. Abdul Rashid Waziri, Head of the Department of Nationalities, Tribes and Borders Affairs of the PDPA CC was also present (KNT, 23 May).

b. Jirga Addressed by Haji Mohammad Chamkani

(i) Jirga of Pro-Afghan elders of Wali Khel Wazir tribe of North Waziristan Agency (Pakistan) at Gulkhana Palace, Kabul on May 3, 1987 (Radio Kabul, 4 May).

(ii) Jirga of elders of Begram district, Parwan Province at Gulkhana Palace, Kabul on May 5, 1987 (Radio Kabul, 6 May).

(iii) Jirga of elders of Bamian Province at Gulkhana Palace, Kabul on May 6, 1987. Mohammad Ewaz Nabizada, Deputy Minister of Nationalities and Tribes Affairs and Sheikh Mohammad Azim, President of the Provincial Council of People's representatives (governor of Province) were also present (KNT, 7 May).

(iv) Jirga of some Pro-Afghan elders from tribal area of Pakistan at Gulkhana Palace, Kabul on May 16, 1987 (KNT 17 May).

c. Jirgas Addressed by Other High-ups

(i) Jirga of elders of Bamian Province on May 3, 1987 by 
Sultan Ali Keshtmand, Chairman of DRA Council of Ministers at his office (KNT, May 4).

(ii) Jirga of elders of Aibi, Khajuri and Mirzaka Mangal, Ahmadzai, Tota Khel, Gardezi tribes and Shiite of Gardez town on May 16, 1987 at Gardez by Suleman Laeq, Minister of Nationalities and Tribes Affairs (KNT, 17 May).

\section{Women}

The number of girl students in schools and universities have considerably increased compared to pre-revolution years, more than two times the number of boys. There were 700,000 school students, 377,000 literacy learners and 13,114 university students in 1986. Of them $234,000,16,000$ and 6,385 students were girls. The number of women teachers increased by 49 per cent. For instance there are 122 and 11,000 women teachers in the universities and schools. AAWC and DYOA have carried out important activities for enlightening the public and for elevating the role of women in the society (KNT, 10 May).

Thirty-five women who recently returned in Kunduz province have acquired the membership of the women council of Chardara district. One of the newly returnees was elected as chair person of this council. Welcoming the national reconciliation policy over 320 women joined the women council of Kunduz province in the months of March and April 1987 (KNT, 20 May).

\section{0,000 Afghan Refugees Return Home Since January-15}

The Afghan Government spokesman Jilani Karger (ph) has stated that the policy of national reconciliation, pursued by the Afghan leadership, is aimed at ending bloodshed and restoring peace in the country.

Speaking before journalists in Bangkok (Thailand), he said that since January 15 th, when national reconciliation was announced over fifty thousand refugees have returned home from Pakistan and Iran. Talks are in progress about return who left the country under the influence of counter-revolutionary propaganda. The number of returning refugees will be still greater, if the authorities in Iran and Pakistan don't interfere (Radio Moscow, 30 April).

\section{Twenty Thousand People Lay Down Arms in Response to National Reconciliation Policy}

In Afghanistan members of the armed anti-government groups who intending to end bloodshed are joining the government. About one hundred groups comprising more than twenty thousand persons laid 
down their arms following proclamation of the national reconciliation policy in January this year. Negotiations are with hundreds other groups on national reconciliation policy. About fifth thousand Afghans have returned to their homeland (Radio Moscow, 28 May).

\section{Members of Afghan Government Celebrate Eid}

The Secretary General of Afghanistan Democratic Khalq Party Central Committee Comrade Najibullah, the member of the Afghanistan Democratic Khalq Party Politburo and Chairman of the Council of Ministers of Democratic Republic of Afghanistan Comrade Sultan Ali Kishtmand and other party leaders alongwith thousands of citizens offered Eid prayers at the Kabul Jamia Mosque on Eid day (28 May). Later on, they prayed for the progress and prosperity of the country. On the occasion, people also prayed for an end to bloodshed in the country and for the success of the Government's policy of national reconciliation. Afterwards, the people embraced each other and exchanged greetings ( Radio Kabul, 28 May).

\section{4-ECONOMY}

\section{Protocols}

A trade cooperation protocol was signed on May 24, between the DRA and Mongolian People's Republic. The protocol provides for the first time the ground for direct and barter trade relations between the two countries. By the end of 1987, at the cost of 3.2 million dollars, goods including dry fruit and handicrafts of Afghanistan will be exported to Mongolia in exchange, foodstuff will be imported from that country (KNT, 25 May).

A memorandum of understanding and a commercial protocol were signed on May 10 between the DRA and Romania. According to the protocol the main directions of technical and economic cooperation are marked off in the fields of light industries, mines, agriculture, construction, technical and economic studies shall soon be carried thereon. The two way trade will expand and the Romanian side has expressed readiness to contribute to state and private sectors and in forming mixed trading companies. Technical and economic cooperation contracts will be signed in future between the two countries (KNT, 11 May).

\section{Industry}

The government pays maximum attention to the development and growth of light industries, particularly cotton, rayon and woollen, textiles, which constitute the primary textile needs of the country. The 
DRA has reactivated Kabul textile mills, Kabul weaving and Kabul spinning mills. At present, there are 26 textile factories functioning in the country out of which 14 are in the private sector and the remaining 12 in the state sector. These factories had produced over 62.858 million metres of cotton, woollen and rayon fabrics in 1986. Further increase is expected in the 1987 expansion plan for the textile industry (KNT, 24 May).

Ministry of Light Industry and Foodstuffs produced commodities worth of 8240 million Afghanis in 1987 showing 5 per cent increase over the production in 1985. A source of the Ministry said: The Ministry has 29 production institutions in the fields of cotton, oil, ghee, rayon and woollen textile. The source added that 13,000 tons of cotton 3,444 tons of oil and ghee, 262 tons of soap, 58 million metres of rayon and cotton cloth over 268,000 metres of woollen textiles 10.5 tons of sugar and wood products worth 204 million Afghanis were produced by these institutions (KNT, 14 May).

The cotton textile mills of Herat province plans to produce one million metres of cotton textiles and 134 tons of thread in 1987. The factory produced 520,770 metres of cotton fabrics and 78.4 tons of thread in 1986 which showed the fulfilment of the plan target by 104 and 102 per cent respectively. The factory was commissioned in 1985 with a capital of over 995 million Afghanis from the state development budget. It is planed to set up a well-equipped technical workshop at a cost of 5.5 million Afghanis (KNT, 27 May).

\section{Factory Inaugurated}

A confectionary and biscuit factory was set up under the policy of national reconciliation, has started functioning in Herat province with an initial capital of 15 million Afghanis and total capital of 90 million Afghanis with the share of 25 national traders of Herat province (KNT, 13 May).

\section{Import and Export}

The volume of imports and exports by the private sector in 1986 has been valued at 537 million and 223 million dollars respectively, registering an increase of 246 million dollars in imports and over 4 million dollars in exports. Stating this a spokesman of the Chamber of Commerce and Industries said, that the share of private sector in external trade has been estimated at 40-50 per cent and the local trade at 82 per cent last year (KNT, 31 May).

The export promotion department of Commerce Ministry has plans this year to export goods valued at over 574 million dollars, 
marking an increase of four per cent over the exports in 1986. The main export items of the country are natural gas, fertilizers, cotton, wool, furs, rugs, carpets, fresh and dried fruits, natural herbs, oil seeds, intestive citrus, olive, handicrafts etc. In 1986 the DRA exports to the USSR valued at 382 million dollars, with the establishment of AfghanNichi Ltd., exports to Japan were also increased (KNT, 4 May).

\section{Projects}

On May 23 the permanent commission of the executive committee of the Council of Ministers of the DRA for domestic and foreign investments approved thirteen projects in the fields of construction, metal works, binding, foodstuffs and carpet washing (KNT, 24 May).

\section{Private Sector}

According to the officials of Afghan government, private sector is considered important as a source of capital formation and for utilization of domestic savings to serve as a base for further economic development. In 1986 the volume of production in this sector was 6050 million Afghanis which shows an increase of 17 per cent over 1985 . Total 461 private enterprises exist in DRA of which 281 are functioning in the capital and the rest in the provinces. The total investment of these factories is 2,077 million Afghanis and their working capital 4,298 million Afghanis. 219 private enterprises, with an investment of 786 million Afghanis were registered and approved in the post revolution years (KNT, 19 May).

The banks of the DRA have given 15,829 million Afghanis on credit to the private sector during the year 1986, marking an increase of 2.3 times over the year 1978 and 2.1 times over the year 1984 . 1,028 million Afghanis were rendered as credit in the spheres of agriculture, industry and construction, 6,302 million for exports and the remaining amount for imports. The banks have given over 84,449 million Afghanis to the private sector, since the 1978 April Revolution. To improve and strengthen industries in the country, the percentage of interest on Industrial Development Bank loans has been lowered to 6 per cent (KNT, 21 May).

\section{Power Sector}

To achieve complete electrification in the Capital, last year 65 power stations were extended through installing new power generators and 22 others newly built in residential areas. A spokesman of the Ministry of Power and Energy said that the actual power production reached $862 \mathrm{KV} / \mathrm{h}$ last year in the capital and provinces. Also basic 
repairs of electrical equipment were carried out at a cost of 454 million Afghanis in 1986. This year 11,000 new connections were also given to the public (KNT, 7 May).

The foundation stone of Mazar-Sheberghan power sub-station with a capacity of $110 \mathrm{KV}$ was recently laid by the Deputy Chairman of the Council of Ministers in Jargdoq area of Sheberghan city. The construction of the sub-station is estimated at 665 million Afghanis. The station will supply power for the gas purification establishments and the Rankot Petroleum Purification units (KNT, 16 May).

The fourth session of the first round of people's representatives of Kabul city was held on May 14. Sultan Ali Keshtmand also took part in the celeberations. It is mentioned in the report that in 1986 as a whole the state and joint sectors production reached 8.2 billion Afghanis. This figure shows around 10 per cent growth over 1985 . The report adds, to better organise the sale of primary goods for the people, 57 state and cooperative stores were commissioned in Kabul city, and over 1,200 apartments were built in different residential projects of the city and were allotted to the deserving citizens. In 1986 seven schools were newly built and commissioned. 162,000 illiterate people were organised in 5,792 literacy courses of whom around 126,000 were awarded certificates for the competition of courses (KNT, 16 May).

\section{Goods Distributed}

For the year 1987 supply and distribution of essential materials worth about 12 billion Afghanis of the state workers and employees had been envisaged in the plans of the food procurement department of the Ministry of Commerce. These essentials valued at 106 million Afghanis are imported by this department from the friendly countries (KNT, 19 May).

The first caravan of relief and consumer goods of the Uzbek SSR reached at Jauzjan province recently. These goods came under the cooperation protocol concluded recently in the Soviet Union. This includes TV, refregerators, stationaries, cloth, shoes and other consumer goods (KNT, 24 May).

\section{Briefs}

A centre for small handicrafts with an investment of 125 million Afghanis has been added to small industries development centre which was established with an initial capital of 30 million Afghanis and now its capital has reached 34 million Afghanis (KNT, 10 May).

Five consumers cooperatives with a total enrolment of more than 1050 members have been set up recently in Balkh, Herat and Takhar 
provinces (KNT, 20 May).

The avenues of Herat city are going to be reasphalted this year through Soviet assistance (KNT, 24 May).

A carpet weaving company of Jauzjan province, produced 8,500 sqm of carpets and rugs in 1986. Out of which 7,000 sqm carpets were exported to FRG and earned 63 million Afghanis (KNT, 26 May).

\section{Agriculture}

In the spring sowing campaign over 75,000 hectars of cotton and 1500 hectares of sugar beet is being cultivated. According to the Ministry of Agriculture, in order to promote the production of cotton and sugar beet, this year 5250 tons of cotton seed, 30 tons of sugar beet seed, 23,000 tons of chemical fertilizer and sufficient quantity of pesticides, will be distributed through agricultural credit and assistance to individual farmers and agriculture cooperative in various parts of the country (KNT, 2 May).

An area of 22,400 hectares was cultivated with wheat, barley, vegetables and other cereals in the autumn sowing campaign of 1986 in Konar Province, indicating an increase of 6,400 hectares over the year 1985 said spokesman of agriculture and land reforms department of the province (KNT, 3 May).

Agriculture and land reform department of Balkh province have cultivated 1,46,424 hectares of land with wheat, 13,201 hectares with grain, 18,228 hectares with cotton, 1,200 hectares with rice, 3,695 hectares with vegetables, 5,110 hectares with corn, 3,980 hectares with oil crops during the spring and autumn campaign in 1986 in the province. In 1986 more than $16,107,000$ Afghanis were given in credit to individual peasants and 6,369,000 Afghanis to the agricultural cooperatives. Agriculture department of Balkh province has 26 agricultural cooperatives with 8,396 members and 25,79,209 Afghanis as share of the cooperatives members ( $K N T, 3$ May).

More than 55,800 Jeribs of land (over 11,000 hectares) have been cultivated with wheat, oil crops, vegetables and other crops during the spring sowing campaign in Samangan province. A spokesman of agriculture department said that, 19,20,000 Afghanis, 60 tons of improved wheat seeds, 113 tons of fertilizers were given to the peasants (KNT, 5 May).

Agricultural sector is the main source of production and employment in Afghanistan. Its contribution to the total Gross Domestic Product (GDP) is 60 per cent and to the national income 64 per cent. 84 per cent of labour is involved in agricultural activities. Balance of trade shows an average of 40 per cent, of total about 7.9 million 
hectares of land are cultivated annually. Cereals dominate the cropping pattern occupying about 83 per cent of the irrigated land and the whole of dry land. Wheat production is estimated at 2.75 million tons, corn 810,000 tons, rice 480,000 tons and barley 330,000 tons. Necessary measures have been adopted in the Five Year Plan for 1986-1991 to raise the effectiveness of agricultural farms and mechanized agricultural stations (KNT, 5 May).

An income of over 1,500,000 Afghanis was obtained from an area of 4,669 hectares of land cultivated in 1986 by the agricultural mechanized station of Herat province. The head of the agricultural mechanized station of Herat told that fertilizers, improved seeds and pesticides were supplied to the peasants throughout the province. Beside fulfilling its plan target by 115 per cent the station stood third in the work competitions (KNT, 14 May).

The union of peasants cooperatives of Balkh province has earned 6.649 million Afghanis during 1986 from selling goods through its out lets, registering a 350 per cent increase over the year 1985. This was disclosed by Gul Mohammad head of the Supervisory Committee of Balkh peasant cooperatives. The union has 22 consumer cooperatives and three stores of agricultural products in Mazar-e-Sharif. The union imports its required goods from Bulgaria, Czechoslovakia, GDR and the Soviet Union. The union intends to establish two consumer and handicrafts cooperatives and a store of agricultural products in 1987 (KNT, 17 May).

More than 10,000 hectares of land have been cultivated with cotton during the spring sowing campaign of the current year in Balkh province, 700 tons of cotton seeds and 3600 tons of fertilizer were distributed free of charge to the peasants. Agricultural vehicles like tractors, sowers, etc, were also provided to the peasants on easy terms (KNT, 18 May).

The session of the commission on agrarian problems of the PDPA CC and Council of Ministers was held on May 20, 1987. Reviewing the agrarian affairs a number of views and proposals were presented on the basic principles for regulating land and water relations in the DRA (KNT, 23 May).

A consumer cooperative of vegetables and fruits named "Watan" was opened recently with an initial capital of 1.2 million Afghanis in the fourth precinct of Kabul city. There are 250 consumer cooperatives with a total capital of over 60 million Afghanis and a strength of over 100,000 members throughout the DRA. 450 outlets of the cooperatives supply primary goods to the people lower than the open market price (KNT, 14 May). 


\section{5 - EDUCATION YOUTH AND HEALTH}

\section{Protocol}

A cooperation protocol was signed on May 10, between the Ministry of Higher Education of the DRA and the Soviet Union in Kabul. According to the protocol, the Soviet Union will render to the Ministry 2 million Roubles gratis aid for technical schools and 5 million Roubles for the establishment of four new technical and professional schools. The building of a technical school to accommodate 500 students, will be completed in Kabul city with the assistance of the USSR (KNT, 11 May).

The central Institute for Export Specialisation of the DRA has made great achievements for conducting scientific seminars and conferences as well as regulations for various departments and extension of Libraries of the higher educational institutions. 1708 teachers have taken an active part in the seminars held in the provinces of the country in 1986. Similar seminars were also held in the capital and some near by provinces as a result of which 3,653 teachers have got certificates of expert specialisation (KNT, 14 May).

A meeting of instructional personnel of Paktia province was held on May 18, to assess the state of education in Gardez city. The meeting was chaired by Sulaiman Laeq Minister of Nationalities and Tribal Affairs of the DRA. Eight Lycees, eight primary schools, one teacher's training college and one religious Madrassa with the capacity of 2,500 students are functioning in the province (KNT, 19 May).

The Nooristani section of the language and literature Department of the Academy of Sciences of the DRA has achieved a great deal of development of the Nooristani language, folklore and culture. It has recently designed and compiled a written alphabet system for the Nooristani language on the base of scientific method of philology (KNT, 21 May).

At present 10 high madrasas of religious sciences and 10 Darul Hafaaz (school for recitation and memorizing the Holy Quran) are functioning in the centre and provinces in the DRA which trains outstanding and professional cadres with full religious knowledge. At present about 6,700 students of the Madrassas are taught by 400 teachers, 76 students have been graduated from the 14th grades in 1986 and are passing their military service in the armed forces as Mullah Imams. Likewise 90 others have been graduated from the 8th grades of Darul Hafaaz's and are serving the society as recitors of Holy Quran. Over 2,000 students were newly admitted to 9th grade and first grade of Madrassas and Darul Hafaaz in 1987, with the addition of 1,225 
students as compared to 1986 (KNT, 24 May).

The number of kindergartens and their total enrolments increased in the post-revolution years by 15 and 9 folds respectively. Two hundred and ten kindesgartens and crechis with over 20,000 children are now functioning throughout the DRA (KNT, 27 May).

An evening college was inaugurated at Bayazid Roshan University of Ningarhar province recently. A spokesman of the University said that currently, 112 students are enrolled in the college (KNT, 19 May).

The workers complementary school of spinzer plant Kunduz province was set up recently 60 workers who graduated from literacy courses have been enrolled in the school. The school offers educational programme up to 8th grade (KNT, 19 May).

A workers complementary school was set up in the construction unit of the executive committee of the people deputies of the Kabul city (KNT, 21 May).

A functional literacy school was set up in Charikar city of Parwan province. At present 4,163 persons are attending 320 literacy courses in Parwan province (KNT, 27 May).

Two hundred and fifty persons have completed literacy courses since March 21, 1987 till now in Ningarhar province. Three literacy courses were set up recently in Sofian, Kakara and Laghmani villages of Charikar city, with fifty illiterates enrolled (KNT, 12 May).

Youth

Two thousand and one hundred youth joined the armed forces in the months of April and May 1987 in Kabul city. 2,900 youth voluntarily joined the armed forces in the same period, in the zones also encompassing Kabul. Since the beginning of 1987 over 7,500 youth have gone to the 11 precincts of Kabul city and province and joined the armed forces of the DRA (KNT, 12 May).

\section{Health}

The foundation stone of a health clinic by Afghan Red Crescent Society was laid on May 11 in Ghazni. The clinic is being built at the cost of 4,800 Afghanis from the state budget will be completed by the end of 1987 (KNT, 12 May).

In 1986 free medical treatment was provided to more than 28,000 patients in Jauzjan province. A source of provincial health department said that better medical services centres were established and medicines worth 75,000 Afghanis were given free of charge to the patients. 5,646 children were vaccinated against epidemic deseases in the province (KNT, 11 May). 
Institute for 'campaign against Malaria' has performed examinations and medical treatment of more than 400,000 patients of Malaria during 1986. It distributed anti-malaria medicines costing 12,500,000 Afghanis free of charge in the capital and provinces. Since the time of April revolution 2,150 personnel have been trained professionally in the fields of Malaria eradication. The institute is equipped with 146 laboratories equipped with latest equipments. The institute has sent its professional persons for higher studies to the friendly countries (KNT, 14 May).

The construction work of extension of the Indira Gandhi Child Health Institute is in progress. The new complex which will be completed by September 1987 is being built through the assistance of India with 330 million Afghanis. The new complex includes a new Polyclinic, 100 Surgery beds, Operation Theatres, anaesthesia section conference hall X-ray and clinical laboratories and physio-therapy branches (KNT, 31 May).

\section{6- CULTURAL AND SOCIAL}

Plenum of the Central Council of the Journalists Union of the DRA was held on May 24. The Plenum discussed and endorsed the organisational issues. They also endorsed the decision to hold an international conference of Journalists of non-aligned countries in Kabul in the near future (KNT, 25 May).

The International Child Day was marked on May 24 in Kabul. A function was held on the same day, congratulatory message was read out on behalf of the UNICEF. Artistic shows including drama, dance, songs and music were presented in the function (KNT, 25 May).

A Soviet Youth Photo exhibition called "Youth of the Soviet Union in DRA" was opened recently in the Soviet house of Sciences and Culture in Kabul. Hundred and fifty photos were put on display in this exhibition which reflect the role of the Soviet Youth in the victory of Socialist revolution. The aim of this 20 days exhibition is to familiarize the cadres, activists and members of DYOA and youth of the country with the life of Soviet youth and their readiness for convening the just concluded 20th congress of the Komsomol (KNT, 16 May).

The music and theatre sections of the Youth Township of the DYOA have undertaken wide ranging artistic activities to welcome the 9th Anniversary of the April revolution. Gul Surkh (Red Rose) and Sada (Sound) orchestras of the township are recording 15 new popular political and lyric songs for Radio and Television. The Troupe has travelled extensively to Paktia, Khost Division, Mazar-e-Sharif, Baghlan, 
Jalalabad and Herat (KNT, 3 May).

In order to improve the level of knowledge and potentials of the youths and teenagers cultural houses in social art and political spheres are being established by State Committee of Culture in Kabul city. So far 350 youths and teenagers have been trained in the fields of painting, drawing, music, sports and folk dances (KNT, 14 May).

The library hall of the Kabul University was recently a venue to a painting and sculpture exhibition of Murtaza Pardis. His work depicts national reconciliation and follows realism but occasionally he is strongly influenced by mixed style of realism and impressionism. He has created over 200 Canvases sculptures, caricature and posters. The painter has held so far three exhibition of his works in the gallery of Kabul University and also in Tashkent Leningrad and Moscow. He said that works of artists are credible only when he depicts the real life and struggles of his people (KNT, 18 May).

As per the cultural policy of the Party and state for the extension of cultural activities and enlightening of people, a weekly publication has been started in Paktia province. The Periodical appearing every Monday with a circulation of 500 in four pages reflects party and state policies and national reconciliation as well as historical glories of the people (KNT, 12 May).

\section{Religion - Conference on Islam and Peace}

Under the auspices of the DRA Ministry of Islamic Affairs and Trusts, a two day conference on 'Islam and Peace' was held on May 19-20, 1987 at the Islamic Research Centre, Kabul. Some research papers on the subject were read by the local scholars. A statement was also adopted in the conference, on which the Islamic scholars, Ulema and Clergymen who have left the country due to some reasons, were called upon to return home and join the process of national reconciliation.

\section{International Contest of Recitation of Holy Quran}

Ever first International Contest of recitation of Holy Quran was held on May 23-24, 1987 in the Hall of Mailmapal Hotel, Kabul by the DRA Ministry of Islamic Affairs and Trusts. 20 Qaris from Afghanistan, Syria, Lebanon, Libya, Palestine, India, Iraq and Soviet Republic of Uzbekistan participated in the contest. Qari Abdul Mubin from Afghanistan, Qari Samir Ahmed from Libya and Qari Mohammad Shafi Omari from Syria were declared as first, second and third winners and were given cash prizes of Afghanis 150,000, Afghanis 100,000 and Afghanis 50,000 to them respectively (Radio Kabul 23 May and KNT, 25 May). 


\section{Second Nationwide Jirga of Ulema and Clergymen}

The second nationwide.jirga of Ulema and Clergymen of the DRA was held on May 24, 1987 in the Hall of Istiqlal Lycee, Kabul with the following points on its agenda:-

a. The human and Islamic aims behind the policy of National Reconciliation and the unilateral ceasefire of the DRA.

b. Support to the above policy which is in full conformity with the spirit of the Holy Quran and sayings of Prophet Mohammad (PBUH).

c. Provocations and other efforts of the USA and Pakistan for organizing armed interference and aggression in the land of the Afghans.

d. Denouncing of the criminal encroachment of the extremists on the dignity of the people and martyring the religious scholars.

In addition to the local Ulema, Clergymen and other concerned etc, Qaris from certain Muslim countries, India and Uzbek SSR who were already in Kabul in connection with the Holy Quran recitation International Contests also participated in the Jirga. Qari Sheikh Alhaj Mahmood of Lebanon spoke on the occasion and impressed upon the unity of world Muslims.

The Jirga adopted the following documents:-

a. Fatwa of the Jirga.

b. Message to the working Muslims of Afghanistan.

c. Message to the Secretary General of OIC.

d. Message to the religious circles, personalities and leaders of other countries.

e. Message to the Chairman of the NAM.

f. Message to the Secretary General of UNO.

g. Message to the Tribesmen.

Fatwa of the Jirga, inter alia, included the following verdicts:-

a. Every Muslim countrymen is duty bound to help with good efforts and hard work, the measures of the DRA Revolutionary State.

b. All the problems of the country must be solved through consultation in accordance with the instructions of Allah who order 'you must consult in tackling the issues'.

c. We regard all round reiteration to the national reconciliation which conforms to the Quranic instructions and is to the benefit of all Muslims of Afghanistan and condemn the act of those individuals who are reactory to this benevolent issue (Radio Moscow, and $K N T, 25$ May).

Over 1,700 Ulemas and Spiritual figures are propagating religious 
themes of Islam among the residents of Ningarhar province. Maulawi Abed, President of the Department of Islamic Affairs of the province told the news reporters: "The publicists of religion are composed of theology students preachers, custodians of holy places and mullahs Imams. In 1986, the state spent eight million Afghanis for the construction of Moy Mubarak Mosque and for rehabilitation of five other mosques. The state has given Afghanis 6,686,000 to 295 preachers, Imams and custodians of 140 mosques as stipend and over 2,80,000 Afghanis to other ulemas. At present 840 theology students are taught in the madrassas and Darul Hafaazes, where every student is paid Afghanis 500 as pocket money" (KNT, 7 May).

Mawlawi Abdul Manan, member of the high council of Ulema and Clergymen appreciated the government efforts to uphold the Islamic values in the country. He said that since 1978 revolution 231 mosques and takias have been built, 1526 mosques have been repaired and painted throughout the country (KNT, 13 May).

In the Islamic Research Centre, Najib met, on May 13 the members of the Ministry of Islamic Affairs and Religious Trusts, members of Supreme Council of Ulema and Clergymen, members and staff of the faculty of Theology of Kabul University. The leadership of Afghanistan attach profound value to the noble activities of Ulema and Clergy, render all round assistance to them and practically help them. The Ulema and Clergymen also presented a series of proposals to Najib in context of the realisation of the national reconciliation (KNT, 14 May).

The complete recitation of Holy Quran which began in the start of Ramadan (fasting month) in a number of mosques of Kabul city ended recently: A cash of 260,000 Afghanis was distributed to Hufaaz in a meeting held in Shah-e-Doshamshira mosque (KNT, 19 May).

Najib attended the mourning ceremony of Late Haji Mohammad Nabi, Mullah Imam of the congregational mosque of Holy Kherqa of Qandahar city on May 23 and paid homage to the deceased (KNT, 24 May).

In the light of policy of national accord, the department of Islamic Affairs and Religious Trusts of Herat Province have so far convened 18 sessions of the Ulema and Clergymen. The policy of national reconciliation was explained to over 200,000 people in 290 mosques and takias. Over 300,000 Afghanis were also given to Ulema, Clergymen and Imams by the department during the religions days. About 250 Ulema, Clergymen and Imams are associated with the Council of Ulema and Clergymen of the province in Herat (KNT, 19 May). 


\section{STRATEGIC STUDIES}

(Quarterly Journal)

Published by

The Institute of Strategic Studies

Sector F-5/2

(P.O. Box 1173) Islamabad, Pakistan

Contains Stratagems, Strategic Map Review, Research Articles on Strategy and Allied

Disciplines and Book Reviews

\section{Subscription Rates:-}

Annual : Pakistan Rs. 50/-

Overseas $\$ 10 /-\quad$ (including surface postage)

Single Copy : Pakistan Rs. 15/-

Overseas $\$ 3 /-\quad$ (including surface postage)

Available in all major bookshops in Islamabad, Rawalpindi, Lahore, Peshawar, Quetta, Karachi, and Sialkot. Also reaching out to over 150 centres of learning abroad.

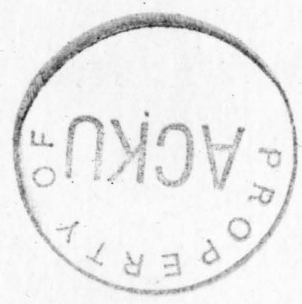

